\title{
Review
}

\section{ATM, a central controller of cellular responses to DNA damage}

\author{
KK Khanna ${ }^{\star, 1}$, MF Lavin ${ }^{1}$, SP Jackson ${ }^{2}$ and TD Mulhern ${ }^{3}$ \\ 1 The Queensland Institute of Medical Research, and Department of Pathology \\ and Surgery, University of Queensland, PO Royal Brisbane Hospital, Brisbane, \\ Qld4029, Australia \\ 2 Wellcome Trust and Cancer Research Campaign Institute of Cancer and \\ Developmental Biology, and Department of Zoology, University of Cambridge, \\ Tennis Court Road, Cambridge CB2 1QR, UK \\ ${ }^{3}$ Department of Biochemistry and Molecular Biology, University of Melbourne, \\ Parkville, 3010, Australia \\ * Corresponding author: KK Khanna, The Queensland Institute of Medical \\ Research, and Department of Pathology and Surgery, University of \\ Queensland, PO Royal Brisbane Hospital, Brisbane, Qld4029, Australia \\ Tel: 61-7-33620338; Fax: 61-7-33620106; E-mail: kumkumK@qimr.edu.au
}

Received 23.01.01; accepted 2.03.01

Edited by G Melino

\begin{abstract}
Mutations in the ATM gene lead to the genetic disorder ataxiatelangiectasia. ATM encodes a protein kinase that is mainly distributed in the nucleus of proliferating cells. Recent studies reveal that ATM regulates multiple cell cycle checkpoints by phosphorylating different targets at different stages of the cell cycle. ATM also functions in the regulation of DNA repair and apoptosis, suggesting that it is a central regulator of responses to DNA double-strand breaks. Cell Death and Differentiation (2001) 8, 1052-1065.
\end{abstract}

Keywords: ATM; p53; BRCA1; Chk1; Chk2; cell cycle checkpoints; DNA repair; apoptosis

Abbreviations: ATM, ataxia-telangiectasia mutated; ATR, ataxia telangiectasia and Rad3-related; PI3-kinase, phosphatidylinositol3 kinase; DSBs, double-strand breaks; NHEJ, non-homologous end joining; HR, homologous recombination

\section{Introduction}

Damage to genomic DNA by various physical and chemical agents occurs throughout the life of an organism. These damaging agents induce an array of lesions in DNA, including base damage, intra- and inter-strand crosslinking and singleor double-strand breaks (DSBs). In most cases, repair of the lesion reconstitutes the physiological DNA structure. If left unrepaired it can lead to induction of gene mutations, chromosomal aberrations and ultimately cell transformation. Alternatively, if an unrepaired DNA lesion interferes with DNA replication or chromosome segregation, this will clearly lead to cell death. To ensure survival, it is therefore anticipated that an effective DNA damage response will be utilised in multicellular organisms to maintain the integrity of the genome. The response is directed not only to repairing damage but also to co-ordinate this with the progress of the cell through the cell division cycle and to activate transcriptional events pertinent to the overall process. As a safeguard, multicellular organisms also have the option of activating apotosis (cell suicide) in the damaged cell rather than risking it becoming cancerous. The choice of response in each instance depends on the cell type, the location and the extent of damage. This review will selectively discuss signalling pathways activated by ionizing-radiation (IR). Many insights into how human cells respond to IR have come from the studies on the human genetic disorder, ataxiatelangiectasia (A-T), which is characterised by hypersensitivity to IR. The gene responsible for this disorder is designated ATM (for ataxia-telangiectasia mutated). In this review, we describe the recent progress in our understanding of signalling pathways triggered by ATM in response to DNA damage. Moreover, we discuss how the ATM protein links the DNA damage response to diverse biological responses.

\section{A-T and radiation sensitivity}

Clinical radiosensitivity was first reported as adverse reactions in A-T patients treated with radiotherapy. ${ }^{1,2}$ These observations were subsequently extended to lymphocytes from A-T patients where increased aberrations were reported post-irradiation compared to controls. ${ }^{3}$ At the same time it was also revealed that fibroblasts from A-T patients were 3-4-fold more sensitive to IR than controls. ${ }^{4} \mathrm{~A}-\mathrm{T}$ heterozygotes are intermediate between homozygotes and controls in their sensitivity to IR. ${ }^{5}$ The increased sensitivity to IR was not associated with a defect in repair of DNA single-strand breaks or in the removal of base damage from DNA in A-T cells. ${ }^{4,6,7}$ Although earlier attempts failed to reveal any significant defect in double-strand break (DSBs) joining at short times after irradiation, Cornforth and Bedford ${ }^{8}$ demonstrated the presence of residual chromosomal breaks in DNA from A-T cells post-irradiation using the premature chromosome condensation assay. Further support for a defect in DSB rejoining in A-T was provided by Coquerelle et $a l,{ }^{9}$ who demonstrated that rejoining of radiation-induced DSBs was slower in A-T fibroblasts than in controls. Consistent with this, it was revealed that the overall extent of repair of breaks did not exceed $90 \%$ of control cells. ${ }^{10}$ Nevertheless, it is evident that A-T cells are largely proficient in repairing breaks in DNA unlike mutants in DNA-PK where most DSBs remain unrejoined. ${ }^{11,12}$ Evidence has also been provided that radiosensitivity in Nijmegen breakage syndrome (NBS) cells is also attributable to a defect in repair of DSBs. ${ }^{13}$ This syndrome has extensive overlap with $A-T$ and, like $A-T$, is characterised by radiosensitivity, immunodeficiency and 
cancer predisposition. ${ }^{14,15}$ In addition, the gene product defective in NBS, NbS1/nibrin, is phosphorylated by ATM in response to DNA damage, as discussed further below. ${ }^{16-19}$

While residual unrepaired breaks could account for the radiosensitivity in $\mathrm{A}-\mathrm{T}$ cells, there is also evidence for an intrinsic abnormality in the chromatin structure in A-T cells that appears to cause more efficient translation of DNA DSBs to chromosome breaks. ${ }^{20}$ As yet the nature of the residual breaks remaining unrepaired in A-T cells has not been identified, but could represent a subcategory of breaks arising due to clustered damage. ${ }^{21}$ It seems likely that residual breaks are signalled to the repair machinery in an ATM-dependent manner and therefore they remain unrepaired in A-T cells and, as a consequence, translate into chromosome breaks. DSBs appear in DNA as a consequence of exposure to IR and other DNA damaging agents, ${ }^{22}$ in response to blocked DNA replication forks ${ }^{23}$ and during normal biological processes such as $T$ and $B$ cell differentiation and meiosis. ${ }^{24,25}$ Therefore, it is not surprising that in syndromes such as A-T and NBS a defective response to radiation-induced breaks is also accompanied by abnormal processing of naturally occurring breaks. ${ }^{26}$ This could explain the complex phenotype in A-T including the radiosensitivity, genome instability, cancer predisposition, meiotic abnormalities, defective $\mathrm{T}$ cell differentiation, and cerebellar degeneration characteristic of this syndrome. ${ }^{27}$

\section{Clinical and cellular biology of A-T}

$A-T$ is an autosomal recessive, rare genetic disorder with a complex phenotype (Figure 1). A-T is characterized by an early-onset progressive cerebellar ataxia which can be explained by progressive cerebellar cortical degeneration involving Purkinje cells and granular cells. The reason for specific loss of Purkinje cells remains unclear but recent data suggest that this cell type may be particularly susceptible to oxidative stress arising as a consequence of loss of ATM, the protein defective in this syndrome. ${ }^{28}$ Telangiectasia is the second major hallmark of this disease and this arises due to dilitation of blood vessels. As for the death of Purkinje cells, it is possible that these changes arise due to oxidative stress from endogenously generated free radicals. Exposure of tissues to radiation, which generates such free radicals during radiotherapy also gives rise to telangiectasia. ${ }^{29}$ The syndrome also includes immunodeficiency with recurrent sinopulmonary infections, cancer susceptibility, and radio-

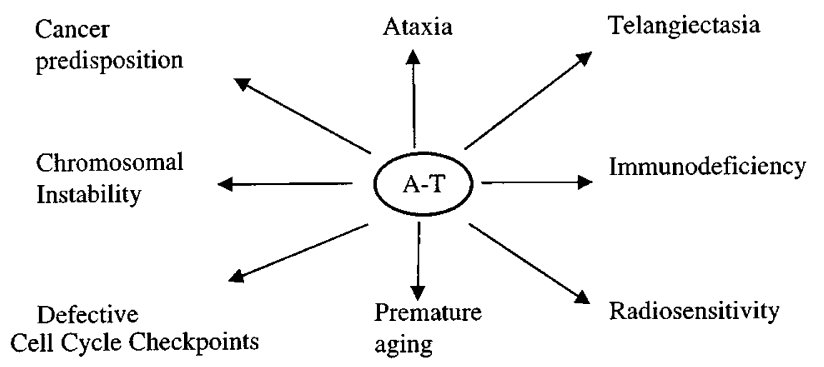

Figure 1 Clinical and cellular phenotypes of ataxia-telangiectasia sensitivity. Compared to the neurological and other features of the disease immunodeficiency is variable with only one-third of A-T patients having severe immune impairment. In some patients a dramatic reduction in antibody responses to viral antigens has been described. ${ }^{30}$ Disturbances in the levels of $\operatorname{lgM}, \operatorname{lgG} 2$ and $\lg \mathrm{A}$ have also been described. ${ }^{31}$ The humoral defect in A-T patients does not appear to be due to reduced $B$ cell numbers but rather due to a defect in B cell differentiation. Abnormal rearrangements involving chromosomes 7 and 14 in the vicinity of the Immunoglobulin genes together with increasing evidence for a role for ATM in recognizing DSBs in DNA could explain defects in $B$ cell differentiation in A-T patients. However, there does not appear to be a defect in the fidelity of $V(D) J$ recombination in $A-T .^{32} A$ developmental defect in lymphoid cells rather than atrophy more readily accounts for the failure to observe a mature thymus in A-T patients. $^{33}$

Aberrant recognition and processing of DSBs may account, not only for the immunodeficiency in A-T, but also for the chromosomal instability and cancer predisposition. Young A-T patients primarily develop leukaemias and lymphomas. Older patients also develop non-lymphoid cancers, such as those of the breast or stomach, and occasionally T-cell prolymphocytic leukaemia. ${ }^{34,35}$ Because of their hypersensitivity to IR, conventional doses of radiotherapy are life threatening for A-T patients. Most patients die either from pulmonary failure or malignancy. $\mathrm{Atm}^{-1-}$ mice also die within 3 months of life due to the development of thymic lymphomas. ${ }^{36,37}$

Since A-T is an autosomal recessive condition it might be expected that A-T heterozygotes would show no symptoms of the disease. However, epidemiological studies suggest that the incidence of mortality from cancer is elevated to some degree in blood relatives of A-T patients. ${ }^{38-40}$ These studies further suggest that mothers of A-T patients are at an increased risk of breast cancer $^{38,41}$ but there has been some dispute in the size of this risk. ${ }^{42}$ With the availability of the ATM gene for mutation analysis, many studies have been initiated to determine whether A-T carriers have an increased susceptibility to breast cancer. Overall, the results appear to be contradictory, studies on patients with breast cancer and breast cancer families have failed to reveal a convincing increase in truncating mutations in the ATM gene. ${ }^{43,44}$ However, the analysis of $A T M$ mutations in a selected group of Dutch breast cancer patients has provided support for the epidemiological findings in families with A-T. ${ }^{45}$ In that study germline mutations in ATM were found in 7 of the $82(8.5 \%)$ patients with breast cancer. There is also some evidence that there may be an enrichment of ATM missense mutations among patients with breast cancer. ${ }^{46,47}$ The recently described functional interaction between ATM and the breast cancer susceptibility gene, BRCA1, has added further fuel to this. ${ }^{48,49}$

\section{The ATM gene and ATM-related proteins}

As several recent publications have reviewed data leading to the identification of $A T M$, the gene mutated in A-T, ${ }^{27,50}$ only an outline will be presented here. The ATM gene was identified 
by Savitsky et al. ${ }^{51}$ The full-length cDNA was eventually cloned in two laboratories and shown to be capable of correcting various aspects of A-T phenotype. ${ }^{52,53}$ Mouse ATM was cloned soon after its human counterpart and was shown to have $84 \%$ overall identity with the human gene. ${ }^{54}$ Disruption of this gene gave rise to a phenotype remarkably similar to A-T except for neurodegeneration, which is largely absent. ${ }^{36,37,55,56}$ Over 300 distinct ATM mutations have been described in A-T families (see http://www.vmmc.org/vmrc/ atm.htm). Most of the mutations identified in A-T families result in premature protein truncation. There is some evidence that missense mutations may have a different functional outcome since missense mutations are overrepresented in cancer patients with T-cell prolymphocytic leukaemia and Bcell chronic lymphocytic leukaemia. ${ }^{46,47}$

The ATM protein is a phosphorylated nuclear protein and is a member of the phosphatidylinositol-3 kinase (PIK) related kinases family. Members in this family are distinguished by their large size and their sequence similarity to the p110 lipid kinase subunit of PI3kinase. ${ }^{57,58}$ To date ATM orthologues have been described from fungi to humans ${ }^{59,60}$ and include Tel1p and Mec1p in Saccharomyces cerevisiae, Tel1 and Rad3 in Saccharomyces pombe, Mei-41 in Drosophila melanogaster, and in mammals, the catalytic subunit of DNA-dependent protein kinase (DNA-PKcs), ataxia-telangiectasia and Rad3-related (ATR) and FRAP1 (FKBP12 and rapamycin associated protein). Table 1 summarises the functions of various family members, and reveals that most of these proteins are involved in cell cycle control and/or the detection of DNA damage. The prototypical member of this family, PI3-kinase has a dual specificity for both proteins and lipids as demonstrated by its phosphorylation of p85 (its regulatory subunit) and the inositol ring of phosphatidyl-inositol. No lipid kinase activity has been reported for DNA-PKcs, ATR, FRAP or ATM. However, these enzymes have been shown to have protein kinase activity against a range of substrates, with specificity for serine/threonine followed by glutamine. ${ }^{61-63}$ Tel1p, Mec1p and Rad3 in yeast also demonstrate protein kinase activity. ${ }^{64-66}$ PIK-related kinases are inhibited by the fungal metabolite wortmanin, as are the prototypical PI3-kinase, providing further evidence of similarity between these enzymes. ${ }^{67,68}$

ATM-related proteins without kinase activity have also been identified. TRRAP (Transformation Transcription domain associated protein) was isolated by affinity chromatography as a nuclear factor that associated with the $\mathrm{N}$-terminus of c-Myc. ${ }^{69}$ This protein is conserved in evolution to its yeast ortholog, Tra1p, which is a subunit of the transcriptional regulatory complex SAGA which includes histone acetyltransferases and transcription adaptors/ coactivators. $^{70,72}$ This complex plays an important role in regulating enhancers by altering chromatin structure. Expression studies showed that mammalian TRRAP is essential for Ras co-transformation of embryo fibroblasts by either Myc or E1A. Consistent with this, it has been demonstrated that mammalian TRRAP might recruit the histone acetyltransferase hGCN5 to presumably activate the function of $\mathrm{c}-\mathrm{Myc}$ in cellular transformation. ${ }^{69}$ The absence of key residues in the Pl-3kinase domain predicts that TRRAP would lack kinase activity and might compete with the normal functions of other ATM family members. However, the recent identification of TRAAP as a component of TIP60 complex, involved in DNA repair, appears to suggest that TRAAP might play an important role in DNA damage response like the other ATM family members. ${ }^{73}$ Notably, the TIP60 histone acetylase complex has ATPase, DNA helicase and structural DNA binding activities and ectopic expression of the mutated TIP60, lacking histone acetylase activity, causes defects in repair of DSBs as well as in signalling the presence of DNA damage to the apoptotic machinery. However, the precise mechanisms by which the TIP-60 complex influences DSB repair are unclear at present.

Table 1 ATM and ATM-related proteins

\begin{tabular}{|c|c|c|c|c|c|}
\hline Protein & Organism & $\begin{array}{l}\text { Amino } \\
\text { acids }\end{array}$ & Activity & Function & Gene disruption (phenotype) \\
\hline$\overline{\text { ATM }}$ & Mammalian & 3056 & Protein kinase & $\begin{array}{l}\text { DNA damage recognition (IR); } \\
\text { cell cycle checkpoint control; } \\
\text { undefined role in repair; } \\
\text { apoptotic functions; } \\
\text { more general signaling }\end{array}$ & $\begin{array}{l}\text { Ataxia-telangiectasia } \\
\mathrm{Atm}^{-1-} \text { mice }\end{array}$ \\
\hline ATR & Mammalian & 2644 & Protein kinase & $\begin{array}{l}\text { DNA damage recognition (UV); } \\
\text { cell cycle control }\end{array}$ & $\begin{array}{l}\text { No known human syndrome; } \\
\text { embryonic lethal in mice }\end{array}$ \\
\hline DNA-PKcs & Mammalian & 4096 & $\begin{array}{l}\text { Protein kinase in } \\
\text { presence of } \mathrm{Ku} \\
\text { heterodimer }\end{array}$ & $\begin{array}{l}\text { NHEJ; V(D) J recombination; } \\
\text { apoptotic functions }\end{array}$ & $\begin{array}{l}\text { No known human syndrome; } \\
\text { severe combined immuno-deficient- } \\
\text { mouse }\end{array}$ \\
\hline FRAP & Mammalian & 2549 & Protein kinase & A central controller of cell growth & No known human syndrome \\
\hline TRRAP & Mammalian & 3828 & No kinase activity & $\begin{array}{l}\text { DNA repair; recruit histone acetylases; } \\
\text { Oncogene activation in } \\
\text { co-transformation assay }\end{array}$ & $\begin{array}{l}\text { No known human syndrome (there may } \\
\text { be one but we might not know of it) }\end{array}$ \\
\hline Mei-41 & D. melanogaster & 2356 & $\begin{array}{l}\text { Activity not } \\
\text { demonstrated }\end{array}$ & $\begin{array}{l}\text { DNA damage recognition; } \\
\text { cell cycle control; recombination }\end{array}$ & Embryonic lethal \\
\hline Tel1p & S. cerevisiae & 2789 & Protein kinase & $\begin{array}{l}\text { Regulation of telomere length; } \\
\text { suppresses hypercombination }\end{array}$ & Short telomeres; radiosensitivity \\
\hline Mec1p & S. cerevisiae & 2368 & Protein kinase & Cell cycle checkpoint activation & Lethal; cell cycle defects \\
\hline Rad3 & S. pombe & 2386 & Protein kinase & $\begin{array}{l}\text { DNA damage recognition; } \\
\text { cell cycle checkpoint control }\end{array}$ & Radiosensitivity; cell cycle defects \\
\hline
\end{tabular}




\section{Domain structure of ATM-related kinases}

Our current understanding of the domain structure of ATMrelated kinases is still rather limited and the 3-dimensional structure has only been determined or predicted for a few domains in these large proteins (summarised in Figure 2). The most characteristic feature of these proteins is a domain near their C-terminus, which shows similarity to the catalytic domain of PI3-Kinase domain. The crystal structure of the p110 subunit of the porcine $\mathrm{PI} 3 \mathrm{~K} \gamma$ has recently been solved ${ }^{74}$ and this may allow for homology modelling of the analogous domains of ATM-related kinases, which might provide important information regarding the substrate recognition and catalytic regulation of these enzymes. Two additional regions of sequence similarity shared by all ATM-related kinases have been recognised. ${ }^{60}$ Several hundred residues $\mathrm{N}$-terminal to the PI3K domain is a region approximately 600 residues in length termed the FAT ( $F$ RAP, ATM and TRRAP) domain and at the extreme $\mathrm{C}$-termini of these proteins is a highly conserved 30 residue tail now termed the FATC domain $^{60,75}$ (Figure 2). The functions of the FAT and FATC regions are unknown as yet, but their recognition as partner domains to the PI3K domain will assist in the recognition of
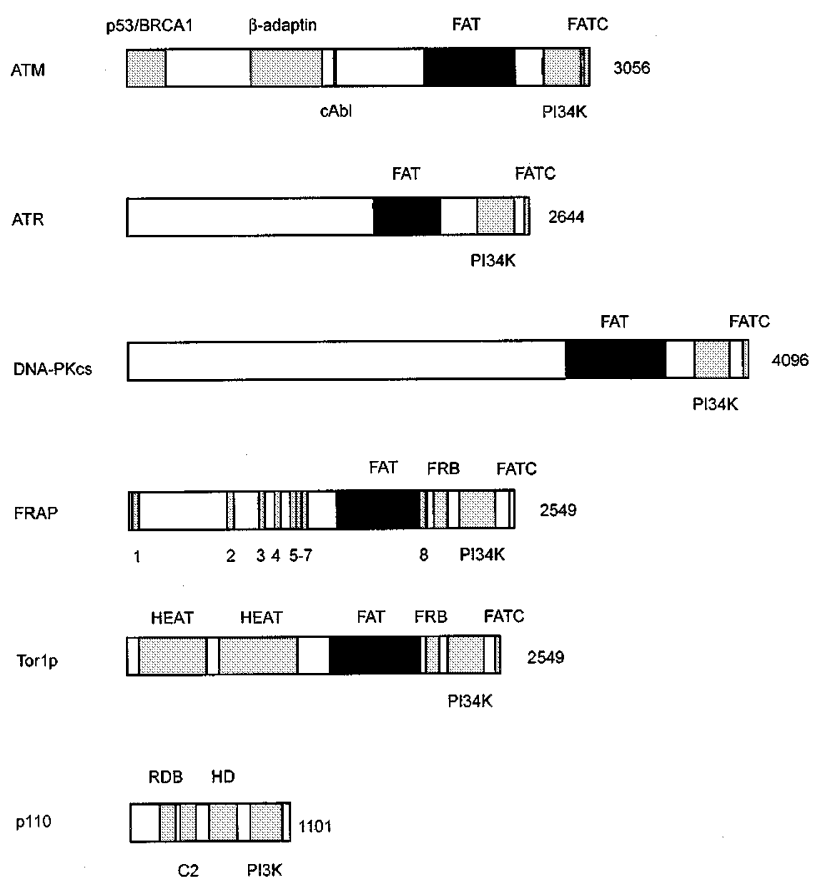

Figure 2 Schematic representation of the domain arrangements in ATMrelated kinases. The positions of the FAT, PI3-Kinase and FATC domains are indicated according to Pfam ${ }^{202}$ analysis of the human sequences. The region of ATM, (res. 1-246), which binds $p 53^{82}$ and $B R C A 1^{49}$ is indicated along with the region which binds $\beta$-adaptin (res. $811-1283)^{83}$ and c-Abl (res. 13731382). ${ }^{84}$ In human FRAP the position of eight $\alpha$-helical HEAT repeats, as per its SWISS-PROT entry (P42345), are indicated (1-8). In Tor1p the two blocks of continuous HEAT repeats (res. $71-522,628-1147$ ) are indicated. $^{79}$ In both FRAP and Tor1p the position of the FRB domains is shown. The domains identified in crystal structure of the $\mathrm{p} 110$ subunit of porcine $\mathrm{PI} 3 \mathrm{~K} \gamma \gamma^{74}$ are indicated: RBD (Ras-binding domain), C2 domain, HD (helical domain) and PI3K. The helical domain of the 1110 subunit of PI3K is composed of five ARM repeats new family members. A PWWP domain has been recognised near the N-terminus of the ATM homologue in Arabidopsis thaliana. ${ }^{76}$ PWWP domains are of unknown structure, but have been recognised in nuclear proteins that play a role in cell growth and differentiation and it has been suggested that the domain is involved in protein-protein interactions. ${ }^{77}$ However, no other ATM protein or any other ATM-related family member identified thus far has been shown to contain a PWWP domain.

The only experimentally determined structure available for any of the family members is that of the FRB (FKBP12rapamycin-binding) domain of human FRAP. ${ }^{78}$ The FRB domain is $\sim 90$ residues in length, adopts a four-helical upand-down bundle topology and binds rapamycin, a potent immunosuppressive compound. Rapamycin is bound in a hydrophobic cleft between $\alpha 1$ and $\alpha 2$ and the portion of rapamycin that does not contact the $\mathrm{FRB}$ domain is able to bind tightly $\left(\mathrm{K}_{\mathrm{d}} 0.2-0.4 \mathrm{nM}\right)$ to the $12 \mathrm{kDa}$ FK506-binding protein (FKBP12), thus mediating the formation of a FRAPrapamycin-FKBP12 complex with minimal contact between the two proteins. However, it does not appear that the FRB domain is conserved across the family and is only found in a subset of ATM-related kinases (e.g. Torlp and Tor2p), which are closely related to FRAP. In these proteins the FRB domain lies in between the FAT and PI3K domains.

The secondary structure prediction for the sequence $\mathrm{N}$ terminal to the FAT and PI3K domains in most ATM-related kinases tends to be extremely rich in $\alpha$-helices (TD Mulhern and KK Khanna unpublished). Interestingly, the mammalian FRAP protein and its yeast homologue Tor1p are predicted to contain $\alpha$-helical HEAT repeats ${ }^{79}$ and one of the HEAT repeats is predicted within the FAT domain of FRAP (Figure 2). HEAT repeats are named after the sequences in which it was first recognised viz Huntington disease protein, Elongation factor 3 (EF3), subunit of phosphatase $2 A$ (PP2A) and TOR1. ${ }^{79}$ The structure of a block of 15 HEAT repeats from PP2A has been solved ${ }^{80}$ and shows that the HEAT repeats are $\sim 40$ residues long, consisting of two anti-parallel $\alpha$-helices and that the repeating units stack to form large superhelical structures. Another feature of note is that the helical domain of the p110 subunit of PI3Ks is composed of similar repeating units, which represent another subfamily in this structural element, which are globally termed ARM repeats. ${ }^{81}$ The association of ARM repeats with these two divergent kinases ( $\mathrm{PI} / 4 \mathrm{Ks}$ and the ATM-related kinases) suggests a long-standing evolutionary relationship between ARM repeats and PI-like kinases.

In human ATM, several regions distant from the kinase domain have been identified that possess protein-binding activity (Figure 2). Thus, a fragment representing residues $1-246$ binds both $\mathrm{p} 53^{82}$ and BRCA $1 ;{ }^{49}$ a two-hybrid study has shown that a region within residues $811-1283$ is able to bind $\beta$-adaptin; 83 and a poly-proline sequence (residues $1373-1382$ ) binds the $\mathrm{SH} 3$ domain of $\mathrm{c}-\mathrm{Abl} .^{84}$ In the past it was predicted that residues 1207-1234 represented a leucine zipper motif. ${ }^{85}$ However, this region lacks the appropriately positioned charged and polar residues that characterize true coiled-coils ${ }^{60}$ and it is possible that the dominant-negative effects seen from $\mathrm{N}$-terminal fragments of $\mathrm{ATM}^{85}$ are due to other protein-protein interactions (e.g. 
p53, BRCA1 or $\beta$-adaptin), rather than homo- or heterodimer formation mediated by the putative leucine zipper.

\section{The ATM-dependent DNA damage response}

Over the past few years, it has become clear that DNA damage response is a signal transduction pathway involving multiple sensors for different types of lesions, transducer molecules and a variety of effector molecules and enzymes for repair. One of the primary and conserved mechanisms for detecting damage and activating cell cycle checkpoints is through the PIK-related kinase family members. Many aspects of DNA damage signalling are highly conserved throughout eukaryotic evolution. For instance, S. cerevisiae Mec1p and S. pombe Rad3 are most closely related to ATR in sequence and play key roles in DNA damage signalling pathways in these organisms. Interestingly, Tellp-the $S$. cerevisiae protein most related to ATM - functions in telomere length regulation as well as working in a partially-overlapping manner to Mec1p in DNA damage signalling. In addition, as with yeast defective in Tellp, human A-T cells display increased rates of telomeric loss. ${ }^{86,87}$ Mammalian ATM and ATR also appear to have related functions, as ATM and ATR display overlapping substrate specificities ${ }^{63}$ and ATR overexpression can complement the radioresistant DNA synthesis phenotype of cells lacking ATM. ${ }^{88}$

Studies in yeast have led to the proposal that DNA damage recognition may be associated with a group of four conserved proteins, Rad1, Rad9, Hus1 and Rad17 (using the $S$. pombe nomenclature). Human homologues of these have been cloned and, as with their yeast counterparts, human Rad1 (hRad1), hRad9 and hHus1 are all related in structure to the DNA replication processivity factor, proliferating-cell-nuclear-antigen (PCNA), ${ }^{89}$ and can form a hetero-trimeric complex. ${ }^{90}$ These findings raise the possibility that, like PCNA, these proteins form a clamp-like structure, and that this structure might be assembled at sites of DNA damage. The fourth conserved protein, hRad17, shares homology with replication-factor-C (RFC) subunits, suggesting a model in which hRad17, either alone or in association with other polypeptides, interacts with damaged DNA and then loads the hRad1/hRad9/hHus 1 complex onto DNA, which in turn leads to the recruitment and activation of ATM and ATR. Although this model is attractive, recent work has suggested that $S$. pombe Rad3 and $S$. cerevisiae Mec1p can be activated in the absence of the above proteins. Thus, phosphorylation of the $S$. pombe DNA damage signalling protein Rad26, in response to DNA damage, is Rad3 dependent but does not require Rad1, Rad9, Rad17 or Hus1. Similarly, Lcd1p (also termed Ddc2p)-which may be the $S$. cerevisiae homologue of $S$. pombe Rad26 $6^{91,92}$ - is phosphorylated after DNA damage in a manner that requires Mec1p but not any of the other DNA damage signalling proteins tested.

Taken together, the available data seem to suggest that Mec1p and Rad3 are either directly or indirectly recruited to the sites of DNA damage. Consistent with this idea, a number of recent studies have provided evidence that ATM and ATR protein can directly or indirectly associate with sites of damaged DNA. For example, It has been reported that ATM can be activated by DNA in vitro and displays an ability to directly bind to DNA termini. ${ }^{93,94}$ Furthermore, ATM binds better to DNA after it has been irradiated. ${ }^{95}$ However, this issue is contentious, as other reports have failed to observe stimulation of ATM kinase activity by DNA in vitro ${ }^{96-98}$ and is a subject of ongoing debate. Nevertheless, a number of more recent studies appear to suggest that both ATM and ATR associate with DNA either directly or indirectly. Human ATR has been reported to bind to DNA and be activated by DNA. ${ }^{99,100}$ Indeed, recent work from Dunphy and colleagues has shown that active Xenopus ATR (X-ATR) can be selectively retrieved from extracts by DNA affinity chromatography. ${ }^{101}$ In this study, DNA-bound $X$-ATR is a much better kinase than non-DNA bound X-ATR towards the non-DNA binding protein PHASI, suggesting that DNA either directly stimulates the kinase activity of ATR or that DNA selectively retrieves an active form of X-ATR. A similar phenomenon has been seen in a Xenopus egg cell-free system in which an S-phase checkpoint was elicited by addition of exogenous DNA DSBs. ${ }^{102}$ This checkpoint requires $\mathrm{X}$-ATM and, upon addition of DSBs, a significant fraction of X-ATM cosediments with damaged, but not bulk DNA. Furthermore, this fraction was highly competent to initiate the S-phase checkpoint, suggesting that DNA damage-bound X-ATM is enriched for the active form of the protein. Thus, X-ATM is either directly activated by DNA ends or is targeted and activated by a cofactor. X-ATR has also been reported to bind chromatin upon initiation of DNA replication, dissociate from chromatin upon completion of replication, but remain associated with chromatin in the presence of inhibitors of replication. ${ }^{103}$ Taken together then, the available data appear to suggest that active ATM and ATR are directly or indirectly targeted to the site of DNA damage. It is therefore tempting to speculate that in this context, they detect the damage in DNA and phosphorylate/activate appropriate proteins to mediate a variety of aspects of the DNA damage response.

\section{Regulation of cell cycle checkpoints by ATM}

The term checkpoint was coined to describe a mechanism that monitors the order of events in the cell cycle to ensure that a cell cycle event occurs only after a prior event has been completed properly. Checkpoints also delay the cell cycle if the DNA is damaged, to avoid replication and segregation of damaged DNA. It appears that a fundamental role of DNA damage checkpoints is to provide time for repair, but it has not been demonstrated conclusively. Nonetheless, recent studies suggest that checkpoint mechanisms are important for the prevention of genetic instability and cancer. ${ }^{104}$ ATM is involved in regulating multiple cell cycle checkpoints (G1/S, $\mathrm{S}$ and $\mathrm{G} 2 / \mathrm{M}$ ) after DNA damage (Figure 3).

\section{G1/S checkpoint}

The defective G1/S checkpoint in A-T appears to be caused primarily by a defect in ATM-dependent phosphorylation of 


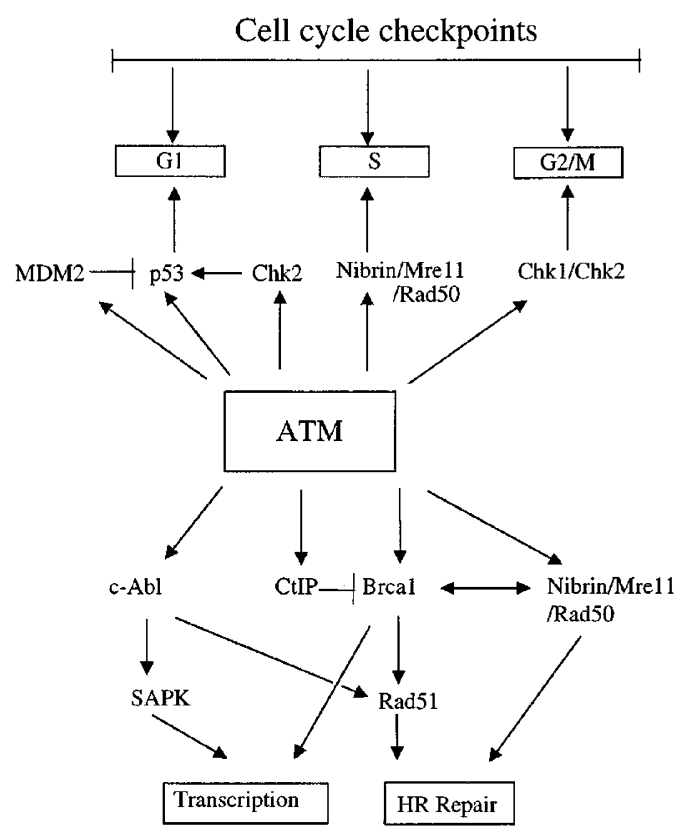

Figure 3 A central role of ATM in cellular response to DSBs. ATM is involved in regulating multiple cell cycle checkpoints, possibly through phosphorylation of different targets at different stages of the cell cycle (see text for detailed description). ATM also signals to repair machinery through its interaction with and phosphorylation of targets implicated in DNA repair. It is also likely that ATM controls the transcription of stress response genes through its interaction with BRCA1 and c-Abl

p53. The notion that p53 is a target of ATM was poineered by work from Kastan and colleagues, ${ }^{105}$ who showed that A-T cells lacked stabilization of p53 as well as p53-mediated G1/S checkpoint in response to IR. However, it was subsequently revealed that the p53 response is not totally absent, but in fact occurs with reduced and delayed kinetics in A-T cells. ${ }^{106}$ Furthermore, cells from A-T homozygotes showed no defect in the p53 response to UV, suggesting that different types of DNA lesion might signal differently to p53, and that ATM is specifically required for $\mathrm{p} 53$ stabilisation after IR. ${ }^{106}$ Since the cloning of the ATM gene, several types of experiments have been performed to address the ATM-p53 connection. Thus, as with A-T patients, Atm-null mice have been found to display a similar abnormality in IR-induced p53 responses. ${ }^{36,107}$ However, when double mutant mice of Atm/p53 were constructed $^{108}$ they displayed a significant advancement of the speed of tumorigenesis relative to either single mutant background, suggesting that ATM and p53 suppress tumorigenesis by separate pathways. Indeed, given the paradox regarding the differences in radiation sensitivity of Atm-deficient and p53-deficient cells, Atm mutant cells are radiosensitive whereas p53 mutant cells are generally radioresistant, the biological relevance of the delayed p53 induction kinetics in A-T cells is still unclear. ${ }^{109}$ Despite these apparent differences between the functions of ATM and p53, it is clear that phosphorylation and stabilization of p53 in response to IR (but not UV) is largely ATM-dependent. ATM phosphorylates p53 directly on Ser-15 in response to $\mathrm{IR}^{82,96,97}$ and in vivo phosphorylation of p53 on Ser-15 in response to IR occurs with delayed kinetics in ATM-deficient cells. ${ }^{82,110}$ p53 is similarly phosphorylated on Ser-15 by both ATR and DNA-PK in vitro. ${ }^{62,99}$ However, since p53 can be stabilised and activated in DNA-PKcs deficient cells, DNA-PK does not play a direct role in IR-mediated activation of p53 in vivo. ${ }^{111}$ On the other hand, studies with cells expressing dominant negative (catalytically inactive) ATR suggest that ATR mediates the ATM-independent delayed phosphorylation of $\mathrm{p53}$ in response to IR as well as the UV-induced rapid phosphorylation response of p53 on Ser-15.112 Taken together then, the available data support a model in which ATM and ATR act in parallel but somewhat overlapping pathways of DNA damage signalling, but respond primarily to different types of DNA lesion.

ATM also regulates the phosphorylation of p53 at other sites, especially Ser-20, by activating other serine/threonine kinases (Chk1 and Chk2) in response to IR. ${ }^{113,114}$ Consistent with this, p53 is not stabilized when thymocytes lacking Chk2 are exposed to IR, although p53 can still be stabilized in response to UV in the absence of Chk2 function. ${ }^{115}$ Notably, thymocytes lacking Chk2 are resistant to apoptosis induced by IR or adriamycin, much like the thymocytes lacking p53. ${ }^{115}$ Genetic evidence for a common pathway for Chk2 and p53 is provided by the demonstration of germline Chk2 mutations in Li-Fraumeni-like cases who do not have mutations in p53. ${ }^{116}$ Taken together, a consensus is therefore emerging in which ATM and its downstream target, Chk2 (which itself depends on ATM for its activation) may synergise to ensure optimal stabilisation and activation of p53. The ATM-dependent phosphorylation sites are close to the region in p53 which binds MDM2 (amino acids 18-23). MDM2 is transcriptionally activated by $p 53$ and is a negative regulator of p53 that also targets p53 for degradation. ${ }^{117,118}$ A number of recent studies suggest that ATM-dependent phosphorylation of p53-direct phosphorylation of Ser15 along with phosphorylation of Ser20 by Chk2 and possibly Chk 1 - contributes to p53 stabilisation by reducing the interaction of p53 with MDM2. ${ }^{119,120}$ Furthermore, ATM-dependent phosphorylation of MDM2 might also contribute to p53 stabilisation. ${ }^{121}$ Dephosphorylation of p53 on serine-376 has also been shown to be ATM-dependent and this is presumably mediated via another effector. Thus, both ATM and its downstream targets appear to act in concert to ensure that p53 is activated only when absolutely required (Figure 3).

The interaction of $\mathrm{c}$-Abl with ATM adds another dimension to the involvement of ATM in cell-cycle control. c-Abl associates directly with both ATM and DNA-PK, and the association with ATM remains unaffected by radiation. ${ }^{84,122}$ Furthermore, activation of $\mathrm{c}-\mathrm{Abl}$ in response to IR is ATM-dependent as ATM-deficient cells are defective in CAbl activation after IR. ${ }^{84,123}$ On the other hand normal activation of $\mathrm{c}-\mathrm{Abl}$ occurs in DNA-PK deficient cells, indicating that ATM but not DNA-PK is required for $c-A b l$ activation. $^{124}$ Furthermore, the ATM catalytic domain directly phosphorylates C-Abl at Ser-465, and phosphorylation of this site increases the catalytic activity of $\mathrm{c}-\mathrm{Abl}$ in vitro. Although the biological significance of these findings remains unclear, one hypothesis is that ATM-dependent cAbl activation contributes to the activation of $\mathrm{G} 1 / \mathrm{S}$ 
checkpoint. ${ }^{125}$ However, this remains controversial, in that data with Abl-null cells both support ${ }^{125}$ and provide evidence to the contrary ${ }^{126}$ for such a function for c-Abl. It is perhaps more likely that this pathway is responsible for transcriptional control. Indeed, there is evidence that c-Abl functions upstream of Stress Activated Protein Kinase (SAPK) in a radiation signal transduction pathway, ${ }^{127}$ and activation of SAPK is defective in A-T cells. c-Abl has also been implicated in the apoptotic response to DNA-damage, as c-Abl deficient mouse fibroblasts and chicken DT-40 cells are more resistant to damage-induced apoptosis. ${ }^{128,129}$ On the other hand, data from ATM-deficient cells appear to suggest that ATM may either trigger apoptosis or maintain cell viability after DNA damage, depending on the cell type. At least with regards to DT-40 cells a direct connection between ATM and c-Abl in damage-induced apoptosis is not apparent because ATMdeficient DT-40 cells are more susceptible to IR-induced apoptosis whereas c-Abl deficient cells are resistant. ${ }^{129,130}$

\section{S-phase checkpoint}

The induction of the S-phase checkpoint is manifested as a slow down of replicative DNA synthesis in response to DNA damage. A-T cells have a defective S-phase checkpoint, as they exhibit radioresistant DNA synthesis in response to IR. These phenotypic features are also observed in cells established from patients with NBS or ataxia-telangiectasia like disorder (AT-LD). Identification of Nbs1/Nibrin (the product of the gene defective in NBS) as a part of complex with Mre11 and Rad50, provided the first link between the Mre11 complex and the S-phase checkpoint. ${ }^{131,132}$ Later, this link was strengthened by the demonstration of hMre11 mutations in patients with A-TLD. ${ }^{133}$ The overlap between the cellular phenotype of A-T, NBS and AT-LD suggests that the Mre11 complex functions in the same pathway as ATM. This hypothesis is supported by the fact that ATM phosphorylates Nibrin (Figure 3) and that mutation of this phosphorylation site disrupts the S-phase checkpoint. ${ }^{16-19}$

Cytological studies have provided some insights in to the mechanism(s) by which the Mre11 complex might participate in the S-phase checkpoint. The Mre11 complex is rapidly recruited to DSBs soon after their induction and becomes a part of foci that remain at the break site for extended periods of time after irradiation. ${ }^{134}$ Recent data reveals that this complex is also located at sites of $V(D) J$ recombination-induced DSBs in immature thymocytes. ${ }^{135}$ It is therefore likely that the Mre11 complex cooperates with ATM to recognise and repair DSBs in DNA. However, lack of ATM-dependent phosphorylation of nibrin does not effect the integrity of the Mre11 complex $^{17}$ and ATM is not required for the recognition and binding of damaged DNA by the Mre11 complex. ${ }^{136}$ Thus, ATM phosphorylation of Nbs1 may occur after the Mre11 complex has associated with DSBs and this modification may assist in maintaining the complex at the site of the break or enhance its association with other proteins involved in DNA DSB repair. Taken together, the available data supports a model in which there is active coupling between ATM-mediated checkpoint controls and DSB repair.
This checkpoint is also thought to regulate replication protein A (RPA). RPA is a trimer consisting of three polypeptides with molecular weights of 70,34 and $11 \mathrm{kDa} .{ }^{137}$ The RPA complex has multiple activities including replication, recombination and repair. RPA localises with ATM to synapsed regions of chromosomes during meiotic recombination, suggesting a possible functional interaction between the two proteins. ${ }^{138}$ Furthermore, the $34 \mathrm{kDa}$ subunit of RPA (RPA-34) becomes phosphorylated at multiple sites after exposure of cells to DNA damaging agents and A-T cells are defective in IR-induced hyperphosphorylation of RPA-34. ${ }^{139}$ ATM has been shown to be capable of phosphorylating RPA directly in vitro although the functional relevance of ATM-dependent phosphorylation of RPA still remains to be elucidated. Notably, radiation-induced phosphorylation of RPA does not apparently alter its ability to support DNA replication or repair raising the possibility that it regulates an as yet unidentified function of RPA in vivo.

\section{G2/M checkpoint}

This checkpoint blocks entry into mitosis if cells incur damage in G2. Unlike normal cells, A-T cells fail to stop their entry in to M-phase when irradiated in G2. Recent studies indicate that G2/M checkpoint control in mammals may be analogous to the pathway involving Rad3, Chk1 and Cds1 in S. pombe. In human cells, IR stimulates phosphorylation/activation of the human orthologs of $S$. pombe Chk1p (hChk1) and Cds1 (hCds1/Chk2) and this Chk2 phosphorylation is ATMdependent. ${ }^{140-142}$ Furthermore, ATM can directly phosphorylate Chk2 on Thr- $68^{143}$ in the $\mathrm{N}$-terminus adjacent to the phospho-aminoacid binding domain called the FHA domain and this ATM-dependent phosphorylation of Chk2 is required for its increased activation after IR. However, prior treatment of cells with caffeine abolishes this damage-induced increase in Chk2 phosphorylation and activity. ${ }^{143}$ This defect in Chk2 activation appears to be due to direct inhibition of ATM kinase activity by caffeine. ${ }^{143,144}$ Taken together the available data suggest that caffeine may abrogate the G2/M checkpoint by inactivating the ATM/Chk2 pathway. Chk2 plays an essential role in the maintenance rather than initiation of $\mathrm{G} 2$ arrest, because Chk2-null ES cells can initiate arrest but cannot maintain long-term arrest. ${ }^{115}$

Like Chk2, Chk1 is also phosphorylated in response to DNA damage, however the activity of Chk1 does not appear to be increased after DNA-damage. ATR can phosphorylate Chk1 directly on Ser- 345 in vitro. ${ }^{145}$ Phosphorylation of Chk1 on Ser-345 is dramatically induced in response to $\mathrm{HU}$ and UV, but only slightly in response to IR. Indeed, there appears to be a greater link between Chk1 and ATR since, like the ATR-null embryos, Chk1-null embryos die early in embryogenesis. ${ }^{146-148}$ Chk1-null blastocysts are incapable of blocking entry into mitosis after treatment with a DNA replication inhibitor or treatment with IR or UV. ${ }^{146}$ The conditional knockout of Chk1 in embryonic stem cells also results in cell death within two cell cycles after loss of Chk1. ${ }^{145}$ Prior to cell death, these cells fail to prevent entry into mitosis in response to DNA damage, demonstrating that Chk1 is required for $\mathrm{G} 2 / \mathrm{M}$ checkpoint control in mammals. Both 
ATR and Chk1 are also involved in regulation of the S-M checkpoint, which prevents premature entry into mitosis if replication is blocked. ${ }^{148}$ Consistent with this, depletion of X-ATR from Xenopus egg extracts leads to loss of Chk1 phosphorylation and premature mitosis in the presence of inhibitors of DNA replication. ${ }^{103}$

How might Chk1 and Chk2 block mitotic entry? Upon activation, Chk1 and Chk2 have been shown to phosphorylate Cdc25C at Ser-216, an activating phosphatase for Cdc2 that dephosphorylates Tyr-15 of Cdc2, to create a binding site for a 14-3-3 protein that prevents Cdc25C from activating CyclinB-Cdc2. ${ }^{149}$ Genetic and biochemical studies in fission yeast support a model in which the G2/ $M$ checkpoint involves inactivation of Cdc25 and its retention in the cytoplasm by 14-3-3 proteins, resulting in its separation from the nuclear cyclinB/Cdk1(Cdc2) complex. ${ }^{150}$ However, this model has not been confirmed by biochemical studies in mammalian cells since, in mammalian cells, cyclinB1/Cdc2 complexes are largely cytoplasmic until the onset of mitosis and are retained in the cytoplasm following DNA damage. ${ }^{151}$ The cytoplasmic localization of cyclin B1 is maintained by both nuclear export as well as by retention of Cdc2-cyclinB1 in the cytoplasm by 14-3-3 $\sigma$, a p53 target implicated in maintaining G2 arrest. ${ }^{152,153}$ In mammalian cells, it is unlikely that 14-3-3 proteins prevent mitotic initiation by exporting Cdc25C, as this would place Cdc25 in the same compartment as cyclinB/Cdc2 and therefore would not provide protection by separation as has been proposed in fission yeast. ${ }^{154}$ Furthermore, Cdc25C is constitutively phosphorylated on Ser-216 throughout interphase in mammalian cells, and DNA damage fails to reveal an increase in Cdc25C phosphorylation and 14-3-3 binding. It is therefore possible that the regulation of the DNA damage checkpoint by Chk1 and Chk2 kinases in mammalian cells is more complicated than the simple model involving Ser-216 phosphorylation and 14-3-3 binding on Cdc25C. Moreover, it is also likely that other components of Cdc2 regulation, such as Wee1, Myt1 and Plk1, are also modified by ATM-dependent pathway in response to DNA-damage.

\section{Regulation of DNA repair}

As mentioned before, A-T cells have a defect in repairing a category of DSBs after IR. At least two distinct processes, homologous recombination (HR) and non-homologous end joining (NHEJ), contribute to efficient repair of DSBs in mammalian cells. ${ }^{155}$ For NHEJ, minimal base-pairing is required at the break site while in $\mathrm{HR}$, repair is directed by homologous DNA sequences. In $S$. cerevisiae the majority of DSBs are repaired by $\mathrm{HR},{ }^{156}$ whereas NHEJ is a major mechanism for DSB repair in mammalian cells. ${ }^{157}$

Genes in the RAD52 epistasis group (RAD51; RAD52 and $R A D 54)$ in $S$. cerevisiae play important roles in the HR repair of DSBs. ${ }^{155}$ Recently, human homologues of these have been identified and have similar biochemical properties. ${ }^{158-}$ 160 The breast cancer susceptibility gene products, BRCA1 and $\mathrm{BRCA} 2$, are also involved in homologous recombination through their association with RAD51. BRCA2 interacts directly with RAD51 whereas interaction of BRCA1 is indirect and possibly mediated by BRCA2 ${ }^{161,162}$ Consistent with this idea, homozygous inactivation of $B R C A 1$ and $B R C A 2$ is embryonic lethal in mouse, as is the loss of Rad51 function. ${ }^{163-165}$ BRCA1-deficient embryonic stem (ES) cells are defective in HR in response to a site-specific DSBs whereas NHEJ appears to be normal in these cells. ${ }^{166}$ BRCA1 and BRCA2-deficient mouse cells are hypersensitive to damaging agents and develop spontaneous chromosomal aberrations consistent with participation of these proteins in DSB repair by HR. ${ }^{166,167}$

In $S$. cerevisiae at least four proteins including Ku70, Ku80, DNA ligase IV and XRCC4 form the core machinery of the NHEJ pathway. ${ }^{168}$ Additional proteins like the Mre11/ Rad50/Xrs2 complex are also involved in NHEJ. ${ }^{169}$ There is also evidence that Mre11/ Rad50/ Xrs2 also participates in $\mathrm{HR}$ in S. cerevisiae. ${ }^{170}$ Most of these proteins are conserved in vertebrates with DNA-PKcs being recruited as an additional member to DNA-bound Ku70/Ku80 heterodimers and Nbs1/Nibrin, presumably corresponding to Xrs2, as part of a complex with Mre11/Rad50.

It is still unclear which of these repair pathways is defective in A-T cells, but several recent studies point to the involvement of ATM in HR. The lack of functional ATM in A$T$ cells results in high rates of intrachromosomal recombination and error prone recombination. The recent knockout of ATM in chicken DT-40 cells has provided evidence for the involvement of ATM in the HR pathway of repair of DSBs in that disruption of the ATM gene caused altered kinetics of radiation-induced RAD51 and RAD54 foci formation. ${ }^{171}$ Furthermore $\mathrm{ATM}^{-1-} \mathrm{Ku}^{-1-}$ double mutant DT-40 cells show more radiosensitivity and higher radiation-induced chromosomal aberrations compared to $\mathrm{ATM}^{-1-}$ DT-40 cells, suggesting that ATM and $\mathrm{Ku}$ work in different pathways. On the other hand $\mathrm{ATM}^{-1-} \mathrm{Rad}^{-1} 4^{-1-}$ doublemutant cells show almost the same radiosensitivity and chromosomal abberation profile as $\mathrm{ATM}^{-1-}$ DT-40 cells, placing ATM and RAD54 on the same HR pathway. While the data from DT40 cells point to a role for ATM in HR, its participation in NHEJ cannot be ruled out because the NHEJ pathway is under-represented in DT40 cells in favour of $\mathrm{HR}$, as compared to the situation in mammalian cells.

In addition, there is an increasing evidence that phosphorylation of some of the proteins involved in HR is either directly or indirectly catalysed by ATM (BRCA1, Rad51; Figure 3). Thus, ATM interacts with and phosphorylates BRCA1 at multiple sites in response to IR and ATMdependent phosphorylations of BRCA1 are required for cellular viability after IR. ${ }^{48,49}$ The ATM downstream target Chk2, also phosphorylates BRCA1 on Ser-988 and this is required for dissociation of BRCA1 from Chk2. ${ }^{172}$ Like ATM, ATR is also a BRCA1 kinase, however, as with p53 the pathways that trigger BRCA1 phosphorylation by these two proteins are in part overlapping, but respond primarily to different types of damaging agents. ${ }^{173,174}$ ATM has also been shown to phosphorylate CtIP (CtBP-interacting protein), a transcriptional repressor which binds BRCA1 and inhibits its function, resulting in its release from BRCA1 and subsequent activation of BRCA $1 .^{175}$ In addition, the ATM downstream target $c-\left.A b\right|^{84,123}$ has been shown to modulate Rad51 activity in response to DNA damage, ${ }^{176,177}$ 
although the possible significance of modulation of Rad51 recombinase function by $\mathrm{c}-\mathrm{Abl}$ remains obscure, as $\mathrm{c}-\mathrm{Abl}$ deficient cells do not show a gross defect in DSB repair or Rad51 foci formation. ${ }^{129}$ These data suggest that ATM has a controlling role in HR through BRCA1 and RAD51. Further evidence for a link between ATM and HR has come from the regulation of the Mre11 complex by ATM, as discussed in relation to the S-phase checkpoint. In addition, Both ATM and BRCA1 are components of a large complex designated BASC (BRCA1 Associated Genome Surveillance Complex), which also contains a number of other repair proteins. ${ }^{178}$ It is possible that these proteins are all regulated by ATM to execute the repair processes.

ATM might also participate in HR through modulation of chromatin structure and/or alter the phosphorylation/ acetylation state of histones to allow access of HR proteins to sites of DNA damage as damage has to be processed in the context of chromatin DNA, rather than naked DNA. Consistent with this, dephosphorylation of histone $\mathrm{H} 1$ after IR is ATM-dependent, ATM associates with histone deacetylases after IR and ATM is also associated with chromatin. ${ }^{179,180}$ A subspecies of histone H2A, H2AX, is modified at sites of DSBs and prior treatment of cells with wortmannin inhibits this phosphorylation, providing evidence for the involvement of PI3-kinases in activating H2AX. ${ }^{181}$ The absence of ATM and DNA-PKcs does not eliminate the $\mathrm{H} 2 \mathrm{AX}$ phosphorylation and foci formation, although they can reduce it substantially, suggesting a potential role for another PI3-kinase that can function in their absence. One might speculate that the activation of $\mathrm{H} 2 \mathrm{AX}$ is probably mediated by ATR in mammals as it is catalysed by the ATR homologue, Meclp, in S. cerevisiae. ${ }^{66}$

\section{Role of ATM in telomere maintenance}

Telomeres are unique structures at the ends of eukaryotic linear chromosomes that consist of repeated DNA sequences. These sequences are synthesised by the ribonucleoprotein complex, telomerase, and are bound by proteins that allow the cell to distinguish natural chromosome ends from damaged DNA. ${ }^{182}$ One critical distinction between telomeres and DNA DSBs is that telomeres are generally protected from end-to end-fusions and nucleolytic degradation whereas DNA strand breaks are not. Indeed, impairment of telomere function through telomere attrition or loss of telomere binding proteins leads to the triggering of DNA damage responses and to telomeres engaging in inappropritate recombination events with one another and with other loci. ${ }^{183,184}$ In mammals, telomeres are covered by binding proteins (TRF1, TRF2 and Rap1) which appear to confer capping properties on telomeres. Recent work has provided evidence that TRF2 is capable of promoting and/or stabilising the formation of a telomere-loop (t-loop) structure, providing a physical means of sequestering the terminus from the cellular activities that act on DNA ends. ${ }^{185}$

Telomere structure is also affected by DNA damage checkpoint proteins. ATM-deficient cells have been found to have unusually short telomeres. ${ }^{86,87}$ Further evidence for the involvement of ATM in controlling telomere length is provided by the observation that expression of a dominant negative fragment of ATM in normal cells, results in a decrease in average telomere length. ${ }^{85}$ The precise role that ATM plays in controlling telomere length is uncertain. However, it has been suggested that the short telomeres in A-T may in part be due to defective telomere metabolism, which is independent of telomerase activity. Inactivation of ATM also leads to altered telomere-nuclear matrix interactions and changed nucleosomal periodicity. ${ }^{186}$ The altered telomeric chromatin could lead to telomere fusions and subsequent loss of telomeres in A-T cells. ATM homologues in fission yeast (Rad3 and Tel1), like Mec1p and Tel1p in budding yeast, affect telomere maintenance. ${ }^{182}$ In fission yeast this pathway is clearly independent of the downstream checkpoint kinase Cds1 and Chk $1,{ }^{187}$ raising the possibility that the ATM homologues may have direct telomeric targets or perhaps directly modify telomere-associated factors to facilitate access of telomerase maintenance activities to the telomeric DNA. However, ATM homologues in yeast have been proposed to have additional roles at telomeres. In $S$. cerevisiae there is a Mec1p/Rad9p dependent redistribution of the repair proteins $(\mathrm{Ku} / \mathrm{Sir}$ complex) from telomeres to the sites of DSBs. ${ }^{188-190}$ However, the details of the mechanism by which DSBs are sensed and how they activate Mec1p still remains to be revealed. Nonetheless, it will clearly be of great interest to establish whether the Mec1p homologues in mammals- ATM and ATR- function similarly in mobilising the repair machinery to DSBs. Consistent with this idea, $\mathrm{Ku}$ is physically associated with telomeres in humans, and therefore, appears to have a direct role in telomere function. ${ }^{191,192}$

In mammalian cells the Rad50/Mre11/nibrin complex has been shown to reside at the telomere. ${ }^{193}$ Mre11 and Rad50 associate with telomeres through most of the cell cycle, while interaction of nibrin is mostly confined to the S-phase. The simple hypothesis that the telomere is a repository for the DNA repair machinery, as has been proposed for yeast, is therefore probably not the case in mammalian cells, as only a minor fraction of the Rad50/Mre11/nibrin complex is located at telomeres and association of the complex with telomeres remains unaltered by irradiation. The transient recruitment of nibrin to telomeres in S-phase in mammals suggests a role for this complex in telomere replication. However, the mechanism by which this complex facilitates replication remains unclear. Nonetheless, it will be of interest to establish whether ATM-dependent phosphorylation of nibrin is essential for recruiting nibrin to telomeres.

\section{ATM and apoptosis}

In A-T certain neurons degenerate and die prematurely. Other cells documented to show apoptotic damage in A-T are the germ cells. In the human A-T syndrome, the neuronal dysfunction tends to precede the germ cell death, and cancers appear later in life. However, in ATM-deficient mice, germ cells degenerate early, and thymic neoplasia precedes the minimal neuronal damage. ${ }^{36,37}$ The mechanism responsible for the differences in phenotype in ATM-deficient humans and mice is still poorly understood. Nonetheless, it is clear that in both systems ATM is critical for repair and recovery after IR, as both human and mouse cells deficient in ATM show decreased clonogenic survival after IR. However, 
the mechanism by which ATM influences IR-induced cell death remains controversial. Studies with Atm-deficient mice suggest a pro-apoptotic role for ATM in IR-induced cell death, especially in the developing central nervous system (CNS). Resistance to IR-induced apoptosis is observed in the developing CNS of ATM knockout mice, like the p53 deficient mice, suggesting that signalling through ATM and p53 is an important determinant of cell death in the developing CNS. ${ }^{194,195}$ Consistent with this, genetic deficiency of ATM or p53 can also rescue excessive neuronal apoptosis observed in ligase IV-deficient mice. ${ }^{196,197}$ A slight resistance to apoptosis was also observed in irradiated Atmdeficient thymocytes. ${ }^{37,108}$ This is consistent with functional interaction between ATM and p53 in DNA damage response. It is conceivable that ATM deficiency may allow damaged cells to be retained in the nervous system, and subsequent dysfunction due to genomic damage, might lead to neurodegeneration. Although this model is attractive, the phenotype of ATM-deficient DT-40 cells is not consistent with this model. When the ATM gene is disrupted in chicken DT-40 $B$ cells, it leads to increased susceptibility to apoptosis induced by radiation, radiomimetics and ceramide. ${ }^{130}$ Higher levels of reactive oxygen intermediates $(\mathrm{ROI})$ were generated in these cells pointing to a defect in ROI-detoxification activities. These observations suggest that, at least in DT40 cells, ATM is critical for cell survival after IR. Consistent with this, some studies have reported that cultured fibroblasts and lymphoblasts from A-T patients are more sensitive to IRinduced apoptosis. ${ }^{198-200}$ Taken together then, the available data appear to suggest that activation of ATM may have divergent roles, as ATM may either trigger apoptosis or afford protection against apoptosis, depending on the cell type.

\section{Summary and future direction}

ATM plays a vital role in multiple functional arenas. Indeed, as suggested by the findings described above, ATM may trigger the activation of multiple signalling pathways that include the activation of cell cycle checkpoints, repair and apoptosis in response to IR. Therefore, ATM can be regarded as a central controller of the cellular responses to DSBs. However, the mechanism of activation of ATM still remains to be determined. This review is focused on the regulation of the DNA damage response by ATM and thus emphasises the nuclear ATM kinase functions. However, this should not be taken to suggest that ATM does not have roles elsewhere in the cell. Indeed, ATM is found mainly in the cytoplasm of neurons and two of the reported targets of ATM are the cytoplasmic proteins ( $\beta$ $\operatorname{adaptin}^{83}$ and 4E-BP1 (PHAS1). ${ }^{201}$ Therefore, it is quite possible that some of the clinical abnormalities seen in A-T patients could represent defects in the cytoplasmic functions of ATM. The immediate challenge is to identify new targets of ATM which will help clarify some of these issues. We also need to understand the mechanistic and physiological relevance of phosphorylation of known targets of ATM, in order to make more definitive functional predictions. An understanding of the multiple roles of ATM will be instrumental in describing how the defect in this one gene product affects so many organ systems. Hopefully, the next decade will witness the description of a mechanistic framework for developing effective strategies for the treatment of A-T. In the process, important clinical benefits are likely to extend to cancer patients, as inactivation of ATM may well provide a therapeutic advantage by increasing the radiosensitivity of tumor cells.

\section{References}

1. Gotoff SP, Amirmokri E and Liebner EJ (1967) Ataxia-telangiectasia. Neoplasia, untoward respons to X-irradiation, and tuberous sclerosis. Am. J. Dis. Child. 114: 617-625

2. Morgan JL, Holcomb TM and Morrissey RW (1968) Radiation reaction in ataxia telangiectasia. Am. J. Dis. Child. 116: 557-558

3. Higurashi M and Cohen EP (1973) In vitro chromosomal radiosensitivity in 'chromosomal breakage syndromes'. Cancer 32: 380-383

4. Taylor AMR, Harnden DG, Arlett CF, Harcourt SA, Lehmann AR, Stevens S and Bridges BA (1975) Ataxia-telangiectasia: a human mutation with abnormal radiation sensitivity. Nature $4: 427-429$

5. Chen PC, Lavin MF, Kidson C and Moss D (1978) Identification of ataxia telangiectasia heterozygotes, a cancer prone population. Nature 274: $484-$ 486

6. Fornace Jr AJ and Little JB (1980) Normal repair of DNA single-strand breaks in patients with ataxia-telangiectasia. Biochem. Biophys. Acta. 607: 432-437

7. Lavin MF and Davidson M (1981) Repair of strand breaks in superhelical DNA of ataxia telangiectasia lymphoblastoid cells. J. Cell. Sci. 48: 383-391

8. Cornforth MW and Bedford JS (1987) On the nature of a defect in cells from individuals with ataxia-telangiectasia. Science 227: 1589-1591

9. Coquerelle TM, Weibezah KF and Lucke-Huhle C (1987) Rejoining of doublestrand breaks in normal human and ataxia-telangiectasia fibroblasts after exposure to Co (-rays, Am "- particles or bleomycin. Int. J. Radiat. Biol. 51: 209

10. Foray N, Priestley A, Alsbeih G, Badie C, Capulas EP, Arlett CF and Malaise EP (1997) Hypersensitivity of ataxia-telangiectasia fibroblasts to ionizing radiation is associated with a repair deficiency of DNA double-strand breaks. Int. J. Radiat. Bio. 72: 271-283

11. Biedermann KA, Sun J, Giaccia AJ, Tosto LM and Brown JM (1991) Scid mutation in mice confers hypersensitivity to ionizing radiation and a deficiency in DNA double-strand break repair. Proc. Natl. Acad. Sci. USA 88: 1394- 1397

12. KirchgessnerCU, Patil CK, Evans JW, Cuomo CA, Fried LM, CarterT, Oettinger MA and Brown JM (1995) DNA-dependent kinase (p350) as a candidate gene for the murine SCID defect. Science 267: 1178-1183

13. Girard P-M., Foray N, Stumm M, Waugh A, Riballo E, Maser RS, Phillips WP, Petrini J, Arlett CF and Jeggo PA (2000) Radiosensitivity in Nijmegen Breakage Syndrome Cells is Attributable to a Repair Defect and not Cell Cycle Checkpoint Defects. Cancer Research 60: 4881-4888

14. Weemaes CM, Smeets Df and van der Burgt CJ. Nijmegen Breakage syndrome: a progress report. Int. J. Radiat. Biol. 66: S185-S188

15. van der Burgt I, Chrzanowska KH, Smeets D and Weemaes C (1996) Nijmegen breakage syndrome. J. Med. Genet. 33: 153-156

16. Lim DS, Kim ST, Xu B, Maser RS, Lin J, Petrini JH and Kastan MB (2000) ATM phosphorylates p95/nbs 1 in an S-phase checkpoint pathway. Nature 404: 613-617

17. Gatei M, Young D, Cerosaletti KM, Desai-Mehta A, Spring K, Kozlov S, Lavin MF, Gatti RA, Concannon P and Khanna KK (2000) ATM-dependent phosphorylation of nibrin in response to radiation exposure. Nature Genetics 25: $115-119$

18. Zhao S, Weng YC, Yuan SS, Lin YT, Hsu HC, Lin SC, Gerbino E, Song MH, Zdzienicka MZ, GatRA, Shay JW, Ziv Y, Shiloh Y and Lee EY (2000) Functional link between ataxia-telangiectasia an Nijmegen breakage syndrome gene products. Nature 405: 473-477

19. WuX, Ranganathan V, Weisman DS, Heine WF, Ciccone DN, O'Neill TB, Crick KE, Pierce KA Lane WS, Rathbun G, Livingston DM and Weaver DT (2000) ATM phosphorylation of Nijmege breakage syndrome protein is required in a DNA damage response. Nature: 405: 477-482

20. Hittleman WN and Pandita TK(1994) Possible role of chromatin alteration in the radiosensitivity of ataxia-telangiectasia. Int. J. Radiat. Biol.66(6 Suppl): S109 S113. Review.

21. Nikjoo H, O'Neill P, Goodhead DT and Terrissol M (1997) Computationa modelling of low-energy electron-induced DNA damage by early physical and chemical events. Int. J. Radiat. Biol. 71: 467-483 
22. Lett JT (1992) Damage to cellular DNA from particulate radiations, the efficacy of its processing and the radiosensitivity of mammalian cells. Emphasis on DNA strand breaks and chromatin breaks. Radiat. Environ. Biophys. 31: 257-277

23. Michel B, Ehrlich SD and Uzest M (1997) DNA double-strand breaks caused by replication arrest. EMBO J. 16: $430-438$

24. Haber JE (1998) Meiosis: Avoiding inappropriate relationships. Curr. Biol. 8 $\mathrm{R} 832-\mathrm{R} 835$

25. Lieber MR (1998) Warner-Lambert/Parke-Davis Award Lecture. Pathologica and physiological double-strand breaks: roles in cancer, aging, and the immune system. Am. J. Pathol. 153: 1323-1332

26. Chao C, Yang EM and XuY (2000) Rescue of defective T cell development and function in Atm-/- mice by a functional TCR alpha beta transgene. J. Immunol. 64: $345-349$

27. Lavin MF and Shiloh Y (1997) The genetic defect in ataxia-teleganiectasia. Ann Rev. Immunol. 15: 177-202

28. Rotman $G$ and Shiloh $Y$ (1999) ATM: a mediator of multiple responses to genotoxic stress. Oncogene. 18: 6135-6144. Review

29. Bentzen SM and Overgaard M (1991) Relationship between early and late normal-tissue injury after postmastectomy radiotherapy. Radiother Oncol 20: $159-165$

30. Waldmann TA (1982) Immunological abnormalities in ataxia-telangiectasia. In Ataxia-Telangiectasia: A Cellular and Molecular Link between Cancer, Neuropathology, and Immune Deficiency. B.A. Bridges, and D.G. Harnden (eds) John Wiley Sons. pp. 37-52

31. Stobo JD and Tomasi TB (1975) Editorial: Aging and the regulation of immune reactivity. J. Chronic. Dis. 28: 437-440

32. Hsieh Cl, Arlett CF and Lieber MR (1993) V(D)J recombination in ataxia telangiectasia, Bloom's syndrome and a DNA ligase I-associated immunodeficiency disorder. J. Biol. Chem. 268: 20105-20109

33. Peterson RD, Kelly WD and Good RA (1964) Ataxia-telangiectasia: Its association with a defective thymus, immunological-defective thymus, immunological-deficiency disease, and malignancy. Lancet 1: 1189-1193

34. Spector BD, Filipovich AH, Perry III GS and Kersey JH (1982) Epidemiology of cancer in ataxia telangiectasia. In Ba Bridges and Dg Harnden (Eds). Ataxiatelangiectasia. New York: J. Wiley and Sons Ltd

35. Hecht $F$ and Hecht BK (1990) Cancer in ataxia-telangiectasia patients. Cance Genet. Cytogenet. 46: 9-19

36. Barlow C, Hirotsune S, Paylor R, Liyangage M, Eckhaus M, Collins F, Shiloh Y Crawley JN, Ried T, Tagle D and Wynshaw-Boris A(1996)Atm-deficientmice: a paradigm of ataxia telangiectasia. Cell. 86: 159-171

37. Xu Y, Ashley T, Brainerd EE, Bronson RT Meyn SM and Baltimore D (1996) Targeted disruption of ATM leads to growth retardation, chromosomal fragmentation during meiosis, immune defects and thymic lymphomas. Genes Dev. 10: 2411-2422

38. Swift M, Morrell D, Massey RB and Chase CL (1991) Incidence of cancer in 161 families affected by ataxia-telangiectasia. N. Eng. J. Med. 325: 1831-1836

39. Pippard EC, Hall AJ, Barker DJ and Bridges BA (1988) Cancer in homozygotes and heterozygotes of ataxia-telangiectasia and xeroderma pigmentosum in Britain. Cancer Res. 48: 2929-2932

40. Borresen AL, Anderson TI, TretliS, Heiberg A and MollerP (1990) Breastcance and other cancers in Norwegian families with ataxia-telangiectasia. Genes Chrom Cancer 2: $339-340$

41. Olsen JH, Hahnemann MJ, Borresen-Dale A-L, Brondum-Nielsen $\mathrm{K}$ Hammarstrom L, Kleinerman R, Kaariainen H, Lonnqvist T, Sankila R, Seerholm N, Tretli S, Yuen J, Boice JD and Tucker M (2001) Cancer in patients with ataxia-telangiectasia and in their relatives in the nordic countries. JNCI 93: $121-127$

42. Easton DF (1994) Cancer risks in A-T heterozygotes. Int. J. Radiat. Biol. 66: S177-S182

43. Fitzgerald MG, Bean JM, Hedge SR, Unsal H, MacDonald DJ, Harkin DP, Finkelstein DM, Isselbacher KJ and Haber DA (1997) Heterozygous ATM mutations do not contribute to early onset breast cancer. Nature 15: 307-310

44. Chen J, Birkholtz GG, Lindblom P, Rubio C and Lindblom A (1998) The role of ataxia-telangiectasia heterozygotes in familial breast cancer. Cancer. Res. 58: $1376-1379$

45. Broeks A, Urbanus JH, Floor AN, Dahler EC, Klijn JG, Rutgers EJ, Devilee P, Russell NS, van Leeuwen FE and van't Veer LJ (2000) ATM-heterozygous germline mutations contribute to breast cancer-susceptibility. Am. J. Hum. Genet. 66: 494-500
46. Gatti RA, Tward A and Concannon P (1999) Cancer risk in ATM heterozygotes: a model of phenotypic and mechanistic differences between missense and truncating mutations. Mol. Genet. Metab. 68: 419-423. Review.

47. Khanna KK (2000) Cancer risk and the ATM gene: a continuing debate. J. Natl. Cancer. Inst. 92: 795-802. Review.

48. Cortez D, Wang Y, Qin J and ElledgeSJ (1999) Requirement of ATM-dependent phosphorylation of brac1 in the DNA damage response to double-strand breaks. Science 286: 1162-1166

49. Gatei M, Scott SP, Filippovitch I, Soronika N, Lavin MF, WeberBand Khanna KK (2000) Role for ATM in DNA damage-induced phosphorylation of BRCA1. Cancer Research 60: 3299

50. Shiloh Y (1995) Ataxia-telangiectasia: Closer to unraveling the mystery. Eur. J. Hum. Genet. 3: 116-138

51. SavitskyK, Bar-ShiraA, GiladS, Rotman G, ZivY, Vanagaite L, Tagle DA, Smith S, Uziel T, Sfez S, Ashkenazi M, Pecker I, Frydman M, Harnik R, Patanjali SR, Simmons A, Clines GA, Sartiel A, Gatti RA, Chessa L, Sanal O, Lavin MF, Jaspers NGJ, Taylor MR, Arlett CF, Miki T, Weissman SM, Lovett M, Collins FS and Shiloh Y (1995) A single ataxia telangiectasia gene with a product similar to PI-3 kinase. Science 268: 1749-1753

52. Zhang N, Chen P, Khanna KK, Scott S, Gatei M, Kozlov S, Watters D, Spring K, Yen T and Lavin MF (1997) Isolation of full-length ATM cDNA and correction of ataxia-telangiectasis cellular phenotype. Proc. Natl. Acad. Sci. USA. 94: $8021-8026$

53. Ziv Y, Bar-Shira A, Pecker I, Russell P, Jorgensen TJ, Tsarfati I and Shiloh Y (1997) Recombinant ATM protein complements the cellular A-T phenotype. Oncogene 15: 159-167

54. Pecker I, Avraham KB, Gilbert DJ, Savitsky K, Rotman G, Harnik R, Fukao T, Schröck E, Hirotsune Sh, Tagle DA, Collins FS, Wynshaw-Boris A, Ried T, Copeland NG, Jenkins NA, Shiloh Y and Ziv Y (1996) Identification and Chromosomal Localization of Atm, the Mouse Homolog of the AtaxiaTelangiectasia Gene. Genomics. 35: 39-45

55. Elson A, Wang Y, Daugherty CJ, Morton CC, Zhou F, Campos-Torres J and Leder P (1996) Pleiotropic defects in ataxia-telangiectasia protein-deficient mice. Proc. Natl. Acad. Sci. USA. 93: 13084-13089

56. Borghesani PR, Alt FW, Bottaro A, Davidson L, Aksov S, Rathbun GA, Roberts TM, SwatW, Segal RA and GuY (2000) Abnormal development of Purkinje cells and lymphocytes in Atm mutant. Proc. Natl. Acad. Sci. 97 7: 3336-3341

57. Zakian VA(1995)ATM-related genes: What do they tell us about functions of the human gene? Cell. 82: 685-687

58. Lavin MF, Khanna KK, Beamish H, Spring K, Watters D and Shiloh Y (1995) Relationship of the ataxia-telangiectasia protein ATM to phosphoinositide 3kinase. Trends Biochem. Sci. 20: 382-383

59. Hoekstra MF (1997) Responses to DNA damage and regulation of cell cycle checkpoints by the ATM protein kinase family. Curr. Opin. Genet. Dev. 7:170175. Review

60. Bosotti R, Isacchi A and Sonnhammer ELL (2000) FAT: a novel domain in PIKrelated kinases. Trends in Biochemical Sciences 25: 225-227

61. Lees-Miller SP, Sakaguchi K, Ullrich SJ, Appella and Anderson CW (1992) Human DNA-activated protein kinase phosphorylates serines 15 and 37 in the amino-terminal transactivation domain of human p53. Mol. Cell. Biol. 12: $5041-5049$

62. O'Neill T, Dwyer AJ, Ziv Y, Chan DW, Lees-Miller SP, Abraham RH, Lai JH, Hill D, Shiloh Y, Cantley LC and Rathbun GA (2000) Utilization of oriented peptide libraries to identify substrate motifs selected by ATM. J. Biol. Chem. 275: 22719-22727

63. Kim ST, Lim DS, Canman CE and Kastan MB (1999) Substrate specificities and identification of putative substrates of ATM kinase family members. J. Biol. Chem. 274: 37538-37543

64. Martinho RG, Lindsay HD, Flaggs G, DeMaggio AJ, Hoekstra MF, Carr AM and Bentley NJ (1998) Analysis of Rad3 and Chk1 protein kinases defines different checkpoint responses. EMBO J. 17: 7239-7249

65. Mallory JC and Petes TD (2000) Protein kinase activity of tellp and mec1p, two saccaromyces cerevisiae proteins related to the human ATM protein kinase. Proc. Natl. Acad. Sci. 9725: 13749-13754

66. Downs JA, Lowndes NF and Jackson SP (2000) A role for Saccharomyces cerevisiae histone H2A in DNA repair. Nature 408: 1001-1004

67. Izzard RA, Jackson SP and Smith GC (1999) Competitive and noncompetitive inhibition of the DNA-dependent protein kinase. Cancer Res. 59: 2581-2586 
68. Sarkaria JN, Tibbetts RS, Busby EC, Kennedy AP, Hill DE and Abraham RT (1998) Inhibition of phosphoinositide 3-kinase related kinases by the radiosensitizing agent wortmannin. Cancer Res. 58: 4375-4382

69. McMahon SB, Van Buskirk HA, Dugan KA, Copeland TD and Cole MD (1998) The novel ATM-related protein TRRAP is an essential cofactor for the C-1 and E2F oncoproteins. Cell. 94 3: 363-374

70. Grant PA, Schieltz D, Pray-Grant MG, Yates YR $3^{\text {rd }}$ and Workman JL (1998) The ATM-related cofactor Tral is a component of the purified SAGA complex. Mol. Cell. 2: 863-867

71. Vassilev A, Yamauchi J, Kotani T, Prives C, Avantaggiati ML, Qin J and Nakatani Y (1998) The $400 \mathrm{kDa}$ subunit of the PCAF histone acetylase complex belongs to the ATM superfamily. Mol. Cell. 2: 869-875

72. Allard S, Utley RT, Savard J, Clarke A, Grant P, Brandl CJ, Pillus L, Workman JL and Cote $\mathrm{J}$ (1999) NuA4, an essential transcription adaptor/histone $\mathrm{H} 4$ acetyltransferase complex containing Esa1p and the ATM-related cofactor Tra 1p. EMBO J. 18: $5108-5119$

73. Ikura T, Ogryzko VV, Grigoriev M, Groisman R, Wang J, Horikoshi M, Scully R, Qin J and Nakatani Y (2000) Involvement of the TIP60 histone acetylase complex in DNA repair and apoptosis. Cell. 102: 463-473

74. Walker EH, Perisic O, Ried C, Stephens L and Williams RL (1999) structural insights into phosphoinositide 3-kinase catalylsis and signalling. Nature 402: $313-320$

75. Keith CT and Schreiber SL (1995) Pik-Related Kinases - DNA-Repair, Recombination, and Cell-Cycle Checkpoints. Science 270:50-51

76. Garcia V, Salanoubat M, Choisne N and Tissier A (2000) An ATM homologue from Arabidopsis thaliana: complete genomic organisation and expression analysis. Nucleic Acids Research 28: 1692-1699

77. Stec I, Nagl SB, van Ommen GJB and den Dunnen JT (2000) The PWWP domain: a potential potein-protein interaction domain in nuclear proteins influencing differentiation? FEBS Letters 473: 1-5

78. Choi JW, Chen J, Schreiber SL and Clardy J (1996) Structure of the FKBP12rapamycin comple interacting with the binding domain of human FRAP. Science 273: 239-242

79. Andrade MA and Bork P (1995) Heat Repeats in the Huntingtons-Disease Protein. Nature Genetic 11: $115-116$

80. Groves MR, Hanlon N, Turowski P, Hemmings BA and Barford D (1999) The structure of the protein phosphatase 2A PR65/A subunit reveals the conformation of its 15 tandemly repeated HEAT motifs. Cell. 96 : $99-110$

81. Groves MR and Barford D (1999) Topological characteristics of helical repeat proteins. Current Opinion in Structural Biology 9: 383-389

82. Khanna KK, Keating KE, Kozlov S, Scott S, Gatei M, Hobson K, Taya Y, Gabriell B, Chan D, Lees-Miller SP and Lavin MF (1998) ATM associates with and phosphorylates p53: mapping the region of interaction. Nature Genetics 20: $398-400$

83. Lim DS, Kirsch DG, Canman CE, Ahn JH, Ziv Y, Newman LS, Darnell RB, Shiloh Yand Kastan B (1998)ATM binds to beta-adaptin in cytoplasmic vesicles. Proc. Natl. Acad. Sci. USA. 95: 10146-10151

84. Shafman T, Khanna KK, KedarP, Spring K, Kozlov S, Yen T, Hobson K, Gatei M, Zhang N, Watters D, Egerton M, Shiloh Y, Kharbanda S, Kufe D and Lavin MF (1997) Interaction between ATM protein and c-Abl in response to DNA damage. Nature 387: $520-523$

85. Morgan SE, Lovly C, Pandita TK, Shiloh Y and Kastan MB (1997) Fragments of ATM which have dominant-negative or complementing activity. Mol. Cell. Biol. 17: $2020-2029$

86. Pandita TK, Pathak S and Geard CR (1995) Chromosome end associations, telomeres and telomerase activity in ataxia telangiectasia cells. Cytogenet. Cell. Genet. 71: 86-93

87. Metcalfe JA, Parkhill J, Campbell L, Stacey M, Biggs P, Byrd PJ and Taylor AM (1996) Accelerated telomere shortening in ataxia telangiectasia. Nat. Genet. 13: $350-353$

88. Cliby WA, Roberts CJ, Cimprich KA, Stringer CM, Lamb JR, Schreiber SL and Friend SH (1998) Overexpression of a kinase-inactive ATR protein causes sensitivity to DNA-damaging agents and defects in cell cycle checkpoints. EMBO J. 17: 159-169

89. Thelen MP, Venclovas C and Fidelis K (1999) A sliding clamp model for the Rad1 family of cell cycle checkpoint proteins. Cell. 96: $769-770$

90. Volkmer E and Karnitz LM (1999) Human homologs of Schizosaccharomyces pombe rad1, hus1, and rad9 form a DNA damage-responsive protein complex. J. Biol. Chem. 274: 567-570
91. Paciotti V, Clerici M, Lucchini G and Longhese MP (2000) The checkpoint protein Ddc2, functionally related to S. pombe Rad26, interacts with Mec1 and is regulated by Mec1-dependent phosphrylation in budding yeast. Genes. Dev. 14: $2046-2059$

92. Rouse $J$ and Jackson SP (2000) LCD1: an essential gene involved in checkpoint control and regulation of the MEC1 signalling pathway in saccharomyces cerevisiae. EMBO J. 19: 5801-5812

93. Smith GC, Cary RB, Lakin ND, Hann BC, Teo SH, Chen DJ and Jackson SP (1999) Purification an DNA binding properties of the ataxia-telangiectasia gene product ATM. Proc. Natl. Acad. Sci. USA. 96: $1134-1139$

94. Gately DP, Hittle JC, Chan GK and Yen TJ (1998) Characterization of ATM expression, localization, and associated DNA-dependent protein kinase activity. Mol. Biol. Cell. 9: 2361-2374

95. Suzuki K, Kodama S and Watanabe M (1999) Recruitment of ATM protein to double strand DNA irradiated with ionizing radiation. J. Biol. Chem. 274: 25571-25575

96. Banin S, Moyal L, Shieh S, Taya Y, Anderson CW, Chessa L, Smorodinsky NI, Prives C, Reiss Y, Shiloh Y and Ziv Y (1998) Enhanced phosphorylation of p53 by ATM in response to DNA damage. Science 281: 1674-1677

97. Canman CE, Lim DS, Cimprich KA, Taya Y, Tamai K, Sakaguchi K, Appella E, Kastan MB and Siliciano JD (1998) Activation of the ATM kinase by ionizing radiation and phosphorylation of $\mathrm{p} 53$. Science 281: 1677-1679

98. Chan DW, Son SC, Block W, Ye R, Khanna KK, Wold MS, Douglas P, Goodarzi AA, Pelley J, Taya Y, Lavin MF and Lees-Miller SP (2000) Purification and characterization of ATM from human placenta. A manganese-dependent, wortmannin-sensitive serine/threonine protein kinase.J. Biol. Chem. 275:7803

99. Lakin ND, Hann BC and Jackson SP (1999) The ataxia-telegantiectasia related protein ATR mediates DNA-dependent phosphorylation of $p 53$. Oncogene 18 : 3989-3995

100. Hall-Jackson CA, Cross DA, Morrice N and Smythe C (1999) ATR is a caffeinesensitive, DNA-activated protein kinase with a substrate specificity distinctfrom DNA-PK. Oncogene 18: 6707-6713

101. Guo Z, Kumagai A, Wang SX and Dunphy WG (2000) Requirement for atr in phosphorylation of chk1 and cell cycle regulation in response to DNA replication blocks and UV-damaged DNA in xenopus egg extracts. Genes. Dev. 14:27452756

102. Costanzo V, Robertson K, Ying CY, Kim E, Avvedimento E, Gottesman M, Grieco D and Gautier J (2000) Reconstitution of an ATM-dependent checkpoint that inhibits chromosomal DNA replication following DNA damage. Mol. Cell. 6: $649-659$

103. Hekmat-Nejad M, You Z, Yee M, NewportJW and Cimprich KA (2000) Xenopus ATR is a replication-dependent chromatin-binding protein required for the DNA replication checkpoint. Curr. Biol. 10: 1565-1573

104. Dasika GK, Lin SC, Zhao S, Sung P, Tomkinson A and Lee EY (1999) DNA damage-induced cell cycle checkpoints and DNA strand break repair in development and tumorigenesis. Oncogene. 18: 7883-7899

105. Kastan MB, Zhan O, El-Deiry WS, Carrier F, Jacks T, Walsh WV, Plunkett BS, Vogelstein B and Fornace AJ (1992) A mammalian cell cycle checkpoint pathway utilizing p53 and GADD45 is defective in ataxia-telangiectasia. Cell. 71: $587-597$

106. Khanna KK and Lavin MF (1993) lonizing radiation and UV induction of $p 53$ protein by different pathways in ataxia-telangiectasia cells. Oncogene. 8: $3307-3312$

107. Xu Y and Baltimore D (1996) Dual roles of ATM in the cellular response to radiation and in cell growth control. Genes. Dev. 10: 2401-2410

108. Westphal CH, Rowan S, Schmaltz C, Elson A, Fisher DE and Leder P (1997) atm and p53 cooperate in apoptosis and suppression of tumorigenesis, but not in resistance to acute radiation toxicity. Nat. Genet. 16: 397-401

109. Westphal CH, Hoyes KP, Canman CE, Huang X, Kastan MB, Hendry JH and Leder P (1998) Loss of atm radiosensitizes multiple p53 null tissues. Cancer Res. 58: 5637-5639

110. Siliciano JD, Canman CE, Taya Y, Sakaguchi K, Appella E and Kastan MB (1997) DNA damage induces phosphorylation of the amino terminus of p53. Genes. Dev. 11: 3471-3481

111. Jimenez GS, Bryntesson F, Torres-Arzayus MI, Priestley A, Beeche M, Saito S, Sakaguchi K, Appella E, Jeggo PA, Taccioli GE, Wahl GM and HubankM (1999) DNA-dependent protein kinase is not required for the 553 -dependent response to DNA damage. Nature $400: 81-83$ 
112. Tibbetts RS, Brumbaugh KM, Williams JM, Sarkaria JN, Cliby WA, Shieh SY, Taya Y, Prives C and Abraham RT (1999) A role for ATR in the DNA damageinduced phosphorylation of p53. Genes. Dev. 13: 152-157

113. Chehab NH, Malikzay A, Appel M and Halazonetis TD (2000) Chk2/hCds1 functions as a DNA damage checkpoint in $\mathrm{G}(1)$ by stabilizing $\mathrm{p} 53$. Genes. Dev. 14: $278-288$

114. Shieh SY, Ahn J, Tamai K, Taya Y and Prives C (2000) The human homologs of checkpoint kinase Chk1 and Cds1 (Chk2) phosphorylate p53 at multiple DNA damage-inducible sites. Genes. Dev. 4: 289-300

115. Hirao A, Kong YY, Matsuoka S, Wakeham A, Ruland J, Yoshida H, Liu D, Elledge SJ and Mak TW (2000) DNA damage-induced activation of p53 by the checkpoint kinase Chk2. Science 287: 1824-1827

116. Bell DW, Varley JM, Szydlo TE, Kang DH, Wahrer DC, Shannon KE, Lubratovich M, Verselis SJ, Isselbacher KJ, Fraumeni JF, Birch JM, Li FP, Garber JE and Haber DA (1999) Heterozygous germ line hCHK2 mutations in Li-Fraumeni syndrome. Science 286: 2528-2531

117. Haupt $Y$, Maya R, Kazaz A and Oren M (1997) Mdm2 promotes the rapid degradation of p53. Nature. 387: 296-299

118. Kubbutat MH, Jones SN and Vousden KH (1997) Regulation of p53 stability by Mdm2. Nature. 387: 299-303

119. Chehab NH, Malikzay A, Stavridi ES and Halazonetis TD (1999) Phosphorylation of Ser-20 mediates stabilization of human p53 in response to DNA damage. Proc. Natl. Acad. Sci. USA. 96: 13777-13782

120. Shieh SY, Ikeda M, Taya $Y$ and Prives C (1997) DNA damage-induced phosphorylation of $p 53$ alleviates inhibition by MDM2. Cell. 91: $325-334$

121. Khosravi R, Maya R, Gottlieb T, Oren M, Shiloh Y and Shkedy D (1999) Rapid ATM-dependent phosphorylation of MDM2 precedes p53 accumulation in response to DNA damage. Proc. Natl. Acad. Sci. USA. 96: 14973-14977

122. Kharbanda S, Pandey P, Jin S, Bharti A, Yuan Z-M, WeichselbaumR, Weaver D and Kufe D (1997) Functional interaction between DNA-PK and c-Abl in response to DNA damage. Nature. 386: 732-735

123. Baskaran R, Wood LD, Whitaker LL, Canman CE, Morgan SE, Xu Y, Barlow C Baltimore D, Wynshaw-Boris A, Kastan MB and Wang JY (1997) Ataxia telangiectasia mutant protein activates $\mathrm{c}-\mathrm{Abl}$ tyrosine kinase in response to ionizing radiation. Nature. 387: 516-519

124. Shangary S, Brown KD, Adamson AW, Edmonson S, Ng B, Pandita TK Yalowich J, Taccioli GE and Baskaran R (2000) Regulation of DNA-dependent protein kinase activity by ionizing radiation-activated abl kinase is an ATMdependent process. J. Biol. Chem. 275: 30163-30168

125. Yuan ZM, Huang Y, Whang Y, Sawyers $C$, Weichselbaum R, Kharbanda S and Kufe D (1996) Role for c-Abl tyrosine kinase in growth arrest response to DNA damage. Nature. 382: 272-274

126. Liu ZG, Baskaran R, Lea-Chou ET, Wood LD, Chen Y, Karin M and Wang JY (1996) Three distinct signalling responses by murine fibroblasts to genotoxic stress. Nature. 384: 273-276

127. Kharbanda S, Ren R, Pandey P, Shafman TD, Feller SM, Weichselbaum RR and Kufe DW (1995) Activation of the c-Abl tyrosine kinase in the stress response to DNA-damaging agents. Nature. 376: 785-788

128. Gong JG, Costanzo A, Yang HQ, Melino G, Kaelin Jr WG, Levrero M, Wang JY The tyrosine kinase $\mathrm{c}-\mathrm{Abl}$ regulates $\mathrm{p} 73$ in apoptotic response to cisplatininduced DNA damage. Nature. 399: 806-809

129. Takao N, Mori R, Kato H, Shinohara A and moto Ki (2000) c-Abl tyrosine kinase is not essential for ataxia telangiectasia mutated functions in chromosomal maintenance. J. Biol. Chem. 275: 725-728

130. Takao N, Li Y and Yamamoto K (2000) Protective roles for ATM in cellular response to oxidative stress. FEBS Letters 472: 133-136

131. Carney JP, Maser RS, Olivares H, Davis EM, Le Beau M, Yates JR 3rd, Hays L, Morgan WF and Petrini JH (1998) The hMre11/hRad50 protein complex and Nijmegen breakage syndrome: linkage of double-strand break repair to the cellular DNA damage response. Cell. 93: 477-486

132. Varon R, Vissinga C, Platzer M, Cerosaletti KM, Chrzanowska KH, Saar K Beckmann G, Seemanova E, Cooper PR, Nowak NJ , Stumm M, Weemaes CMR, Gatti RA, Wilson RK, Digweed M, Rosenthal A, Sperling K, Concannon P and Reis A (1998) Nibrin, a novel DNA double-strand break repair protein, is mutated in Nijmegen breakage syndrome. Cell. 93: 467-476

133. Stewart GS, Maser RS, Stankovic T, Bressan DA, Kaplan MI, Jaspers NG Raams A, Byrd P, Petrini JH and Taylor AM (1999) The DNA double-strand break repair gene hMRE11 is mutated in individuals with an ataxiatelangiectasia-like disorder. Cell 99: 577-587
134. Nelms BE, Maser RS, MacKay JF, Lagally MG and Petrini JH (1998) In situ visualization of DNA double-strand break repair in human fibroblasts. Science 280: $590-592$

135. Chen HT, Bhandoola A, Difilippantonio MJ, Zhu J, Brown MJ, Tai X, Rogakou EP, Brotz TM, Bonner WM, Reid T and Nussenzweig A (2000) Response to RAG-mediated V(D)J cleavage by NBS1 and gamma-H2AX. Science 290: 1962-1965

136. Mirzoeva OKand Petrini JH(2001) DNA damage-dependent nuclear dynamics of the Mre11 complex. Mol. Cell. Biol. 21 1:281-288

137. Budd ME and Campbell JL (2000) Interrelationships between DNA repair and DNA replication. Mutat. Res. 451: 241-255

138. Plug AW, Peters AH, Xu Y, Keegan KS, Hoekstra MF, Baltimore D, de Boer P and Ashley T (1997) ATM and RPA in meiotic chromosome synapsis and recombination. Nat. Genet. 17: 457-461

139. Liu VF and Weaver DT (1993) The ionizing radiation-induced replication protein A phosphorylation response differs between ataxia telangiectasia and normal human cells. Mol. Cell. Biol. 13: 7222-7231

140. Matsuoka S, Huang M and Elledge SJ (1998) Linkage of ATM to cell cycle regulation by the Chk2 protein kinase. Science 282: 1893-1897

141. Chaturvedi P, Eng WK, Zhu Y, Mattern MR, Mishra R, Hurle MR, Zhang X, Annan RS, Lu Q, Faucette LF, Scott GF, LiX, Carr SA, Johnson RK, Winkler JD and Zhou BB (1999) Mammalian Chk2 is a downstream effector of the ATMdependent DNA damage checkpoint pathway. Oncogene 18: 4047-4054

142. Brown AL, Lee $\mathrm{CH}$, Schwarz JK, Mitiku N, Piwnica-Worms $\mathrm{H}$ and Chung JH (1999) A human Cds1-related kinase that functions downstream of ATM protein in the cellular response to DNA damage. Proc. Natl. Acad. Sci. USA 96: 37453750

143. Zhou B-BS, Chaturvedi P, Spring K, Scott SP, Johanson RAR M, Mattern MR, Winkler JD and Khanna KK (2000) Caffeine Abolishes the Mammalian G2/M DNA Damage Checkpoint by Inhibiting Ataxia-Telangiectasia-mutated Kinase Activity. J. Biol. Chem. 275: 10342-10348

144. Blasina A, Price BD, Turenne GA and McGowan $\mathrm{CH}$ (1999) Caffeine inhibits the checkpoint kinase ATM. Curr. Biol. 9: 1135-1138

145. Liu Q, Guntuku S, Cui X, Matsuoka S, Cortez D, Tamai K, Luo G, CarattiniRivera S, DeMayo F, Bradley A, Donehower LA and Elledge SJ (2000) Chk1 is an essential kinase that is regulated by ATR and required for the G2/M DNA damage checkpoint. Genes Dev. 14: 1448-1459

146. Takai H, Tominaga K, Motoyama N, Minamishima $Y A$, Nagahama $H$, Tsukiyama T, Ikeda K, Nakayama K, Nakanishi M and Nakayama K (2000) Aberrant cell cycle checkpoint function and early embryonic death in Chk1 - / mice. Genes Dev. 14: 1439-1447

147. de Klein A, Muijtjens M, van Os R, Verhoeven Y, Smit B, Carr AM, Lehmann AR and Hoeijmakers $\mathrm{JH}(2000)$ Targeted disruption of the cell-cycle checkpoint gene ATR leads to early embryonic lethality in mice. Curr. Biol. 10: 479-482

148. Brown EJ and Baltimore D (2000) ATR disruption leads to chromosomal fragmentation and early embryonic lethality. Genes Dev. 14: 397-402

149. Peng CY, Graves PR, ThomaRS, WuZ, Shaw AS and Piwnica-Worms H(1997) Mitotic and G2 checkpoint control: regulation of 14-3-3 protein binding by phosphorylation of Cdc25C on serine-216. Science 277: 1501-1505

150. Moser BA and Russell $P$ (2000) Cell cycle regulation in schizosaccharomyces pombe. Curr. Opin. Microbiol. 3: 631-636

151. Takizawa CG and Morgan DO (2000) Control of mitosis by changes in the subcellular location of cyclin-B1-cdk1 and cdc25C. Curr. Opin. Cell. Biol. 12: $658-665$

152. Toyoshima F, Moriguchi T, Wada A, Fukuda M and Nishida E (1998) Nuclear export of cyclin B1 and its possible role in the DNA damage-induced G2 checkpoint. EMBO. J. 17: 2728-2735

153. Chan TA, Hwang PM, Hermeking H, Kinzler KW and Vogelstein B (2000) Cooperative effects of genes controlling the $\mathrm{G}(2) / \mathrm{M}$ checkpoint. Genes Dev. 14: 1584-1588

154. O'Connell MJ, Walworth NC and Carr AM (2000) The G2-phase DNA damaage checkpoint. Trends Cell. Biol. 7: 296-303

155. Haber JE (2000) Partners and pathways repairing a double-strand break. Trends Genet. 16: 259-264

156. Aguilera A, Chavez S and Malagon F (2000) Mitotic recombination in yeast: elements controlling its incidence. Yeast 16: 731-754

157. Jeggo PA (1998) Identification of genes involved in repair of DNA double-strand breaks in mammalian cells. Radiat. Res. 150: S80-S91 
158. Bezzubova OY, Schmidt H, Ostermann K, Heyer WD and Buerstedde JM (1993) Identification of a chicken RAD52 homologue suggests conservation of the RAD52 recombination pathway throughout the evolution of higher eukaryotes. Nucleic Acids Res. 21: 5945-5949

159. Bendixen C, Sunjevaric I, Bauchwitz R and Rothstein R (1994) Identification of a mouse homologue of the Saccharomyces cerevisiae recombination and repair gene, RAD52. Genomics. 23: 300-303

160. Kanaar R, Troelstra C, Swagemakers SM, Essers J, Smit B, Franssen JH, Pastink A, Bezzubova OY, Buerstedde JM, Clever B, Heyer WD and Hoeijmakers JHJ (1996) Human and mouse homologs of the Saccharomyces cerevisiae RAD54 DNA repair gene: evidence for functional conservation. Curr. Biol. 6: 828-838

161. Scully R, Chen J, Ochs RL, Keegan K, Hoekstra M, Feunteun J and Livingston DM (1997) Dynamic changes of BRCA1 subnuclear location and phosphorylation state are initiated by DNA damage. Cell. 90: 425-435

162. Chen CF, Chen PL, Zhong Q, Sharp ZD and Lee WH (1999) Expression of BRC repeats in breast cancer cells disrupts the BRCA2-Rad51 complex and leads to radiation hypersensitivity and loss of $\mathrm{G}(2) / \mathrm{M}$ checkpoint control. J. Biol. Chem. 274: $32931-32935$

163. Hakem R, de la Pompa JL, Sirard C, Mo R, Woo M, Hakem A, Wakeham A, Potter J, Reitmair A, Billia F, Firpo E, Hui CC, Roberts J, Rossant J and Mak TW (1996) The tumor suppressor gene Brca1 is required for embryonic cellular proliferation in the mouse. Cell. 85: 1009-1023

164. Suzuki A, de la Pompa JL, Hakem R, Elia A, Yoshida R, Mo R, Nishina H, Chuang T, Wakeham A, Itie A, Koo W, Billia P, Ho A, Fukumoto M, Hui CC and Mak TW (1997) Brca2 is required for embryonic cellular proliferation in the mouse. Genes Dev. 11: 1242-1152

165. Tsuzuki T, Fujii Y, Sakumi K, Tominaga Y, Nakao K, Sekiguchi M, Matsushiro A, Yoshimura Y and Morita T (1996) Targeted disruption of the Rad51 gene leads to lethality in embryonic mice. Proc. Natl. Acad. Sci. USA 93: 6236-6240

166. Moynahan ME, Chiu JW, Koller BH and Jasin M (1999) Brca1 controls homology-directed DNA repair. Mol. Cell. 4: 511-518

167. Patel KJ, Yu VP, Lee H, Corcoran A, Thistlethwaite FC, Evans MJ, Colledge WH, Friedman LS, Ponder BA and Venkitaraman AR (1998) Involvement of Brca2 in DNA repair. Mol. Cell. 3: 347-357

168. Smith GC and Jackson SP (1999) The DNA-dependent protein kinase. Genes Dev. 13: $916-934$

169. Moore JK and Haber JE (1996) Cell cycle and genetic requirements of two pathways of nonhomologous end-joining repair of double-strand breaks in Saccharomyces cerevisiae. Mol. Cell. Biol. 16: 2164-2173

170. Haber JE (1998) The many interfaces of Mre11. Cell. 95: 583-586

171. Morrison C, Sonoda E, Takao N, Shinohara A, Yamamoto K and Tekeda S (2000) The controlling role of ATM in homologous recombinational repair of DNA damage. EMBO. J. 19: 463-471

172. Lee JS, Collins KM, Brown AL, Lee CH and Chung JH (2000) hCds1-mediated phosphorylation of BRCA1 regulates the DNA damage response. Nature 404: 201-204

173. Tibbetts RS, Cortez D, Brumbaugh KM, Scully R, Livingston D, Elledge SJ and Abraham RT (1999) Functional interactions between BRCA1 and the checkpoint kinase ATR during genotoxic stress. Genes Dev. 13: 152-157

174. Gatei M, Zhou BB, HobsonK, Scott S, Young D and Khanna KK(2001)ATMand ATR mediate phosphorylation of Brca1 at distinct and overlapping sites: in vivo assessment using phospho-specific antibodies. J. Biol. Chem. (in press)

175. Li S, Ting NS, Zheng L, Chen P, Ziv Y, Shiloh Y, Lee EY and Lee W-H (2000) Functional link of BRCA1 and ataxia telangiectasia gene product in DNA damage response. Nature 406: $210-215$

176. Yuan ZM, Huang Y, Ishiko T, Nakada S, Utsugisawa T, Kharbanda S, Wang R, Sung P, Shinohara A, Weichselbaum R and Kufe D (1998) Regulation of Rad51 function by c-Abl in response to DNA damage. J. Biol. Chem. 273: 3799-3802

177. Chen G, Yuan SS, Liu W, Xu Y, Trujillo K, Song B, Cong F, Goff SP, Wu Y, Arlinghaus R, Baltimore D, Gasser PJ, Park MS, Sung P and Lee EY (1999) Radiation-induced assembly of Rad51 and Rad52 recombination complex requires ATM and c-Abl. J. Biol. Chem. 274 18: 12748-12752

178. Wang Y, Cortez D, Yazdi P, Neff N, Elledge SJ and Qin J (2000) BASC, a super complex of BRCA1-associated proteins involved in the recognition and repair of aberrant DNA structures. Genes Dev. 14: 927-939

179. Schmidt DR and Schreiber SL (1999) Molecular association between ATR and two components of the nucleosome remodeling and deacetylating complex, HDAC2 and CHD4. Biochemistry 38: 14711-14717
180. Kim ST, Lim DS, Canman CE and Kastan MB (1999) Substrate specificities and identification of putative substrates of ATM kinase family members. J. Biol. Chem. 274: $37538-37543$

181. Paull TT, Rogakou EP, Yamazaki V, Kirchgessner CU, Gellert M and Bonner WM (2000) A critical role for histone H2AX in recruitment of repair factors to nuclear foci after DNA damage. Curr. Biol. 10: 886-895

182. J Kass-Eisler A and Greider CW (2000) Recombination in telomere-length maintenance. Trends Biochem. Sci. Apr. 25: 200-204

183. Hande MP, Samper E, Lansdorp P and Blasco MA (1999) Telomere length dynamics and chromosomal instability in cells derived from telomerase null mice. J. Cell Biol. 144: 589-601

184. van SteenselB, Smogorzewska A and de Lange T (1998) TRF2 protects human telomeres from end-to-end fusions. Cell. 92: $401-413$

185. Griffith JD, Comeau L, Rosenfield S, Stansel RM, Bianchi A, Moss Hand Lange T (1999) Mammalian telomeres end in a large duplex loop. Cell. 97: 503-514

186. Smilenov LB, Morgan SE, Mellado W, Sawant SG, Kastan MB and Pandita TK (1997) Influence of ATM function on telomere metabolism. Oncogene 15: 2659-2665

187. Matsuura A, Naito T and Ishikawa F (1999) Genetic control of telomere integrity in Schizosaccharomyces pombe: rad3(+) and tel1(+) are parts of two regulatory networks independent of the downstreamprotein kinases chk1(+) and cds $1(+)$. Genetics 152: $1501-1512$

188. Mills KD, Sinclair DA and Guarente L (1999) MEC1-dependent redistribution of the Sir3 silencing protein from telomeres to DNA double-strand breaks. Cell 97 $609-620$

189. Martin SG, Laroche T, Suka N, Grunstein M and Gasser SM (1999) Relocalization of telomeric Ku and SIR proteins in response to DNA strand breaks in yeast. Cell 97:621-633

190. McAinsh AD, Scott-Drew S, Murray JA and Jackson SP (1999) DNA damage triggers disruption of telomeric silencing and Mec1p-dependent relocation of Sir3p. Curr. Biol. 9: 963-966

191. Hsu H, Gilley D, Blackburn EH and Chen DJ (1999) Ku is associated with the telomere in mammals. Proc. Natl. Acad. Sci. 96: 12454-12458

192. Bianchi A and de Lange T (1999) Ku binds telomeric DNA in vitro. J. Biol. Chem 274: $21223-21227$

193. Zhu X, Küster, Mann M, Petrini JHJ and de Lange T (2000) Cell-cycle-regulated association of RAD50/MRE11/NBS1 with TRF2 and human telomere. Nature Genet. 25: 347-352

194. Herzog KH, Chong MJ, Kapsetaki M, Morgan JI and McKinnon PJ (1998) Requirement for Atm in ionizing radiation-induced cell death in the developing central nervous system. Science 280: 1089-1091

195. Chong MJ, Murray MR, Gosink EC, Russell HR, Srinivasan A, Kapsetaki M, Korsmeyer SJ and McKinnon PJ (2000) Atm and Bax cooperate in ionizing radiation-induced apoptosis in the central nervous system. Proc. Natl. Acad. Sci. USA 97: 889-894

196. FrankKM, Sharpless NE, Gao Y, SekiguchiJM, Ferguson DO, Zhu C, Manis JP, HornerJ, DePinho RA and AltFW (2000) DNA ligase IV deficiency in mice leads to defective neurogenesis and embryonic lethality via the p53 pathway. Mol. Cell. 5: 993-1002

197. Lee Y, Barnes DE, Lindahl T and McKinnon PJ (2000) Defective neurogenesis resulting from DNA ligase IV deficiency requires. Atm. Genes Dev. 14: 25762580

198. Meyn MS, Strasfeld L and Allen C (1994) Testing the role of p53 in the expression of genetic instability and apoptosis in ataxia-telangiectasia. Int. J Radiat. Biol. 66: S141-S149

199. Liao W-C, Haimovitz-Friedman A, Persaud RS, McLoughlin M, Ehleiter D, Zhang N, Gatei M, Lavin M, Kolesnick R and Fuks Z (1999) Ataxia Telangiectasia-mutated Gene Product Inhibits DNA Damage-Induced Apoptosis via Ceremide Synthase. Journal Biol. Chem. 274: 17908-17917

200. Fritz E, Friedl AA, Zwacka RM, Eckardt-Schupp F and Meyn MS (2000) The yeast TEL1 gene partially substitutes for human ATM in suppressing hyperrecombination, radiation-induced apoptosis and telomere shortening in A-T cells. Mol. Biol. Cell. 11: 2605-2616

201. Yang DQ and Kastan MB (2000) Participation of ATM in insulin signalling through phosphorylation of elF-4E-binding protein 1. Nature Cell. Biol. 2: 893898

202. Bateman A, Birney E, Durbin R, Eddy SR, Howe KL and Sonnhammer ELL (2000) The Pfam protein families database. Nucleic Acids Res. 28: 263-266 